\title{
Analisis Pertumbuhan Ekonomi dan Disparitas Pendapatan Terhadap Kesejahteraan Antar Daerah Kabupaten/Kota di Provinsi Sulawesi Selatan Tahun 2005-2019
}

\author{
Nursa Fitri ${ }^{1}$, Junaiddin Zakaria ${ }^{2}$, Hasbi $^{3}$ \\ ${ }^{1}$ Program Magister Ilmu EkonomiUniversitas Muslim Indonesia, Makassar. \\ 2,3 Fakultas Ekonomi dan Bisnis Universitas Muslim Indonesia, Makassar. \\ Email Korespondensi: $\underline{\text { nursafitri0703@gmail.com }}$
}

\begin{abstract}
Abstrak
Penelitian ini dilakukan dengan bertujuan untuk : (1) menganalisis klasifikasi pertumbuhan ekonomi masingmasing daerah kabupaten/kota di Provinsi Sulawesi Selatan periode tahun 2005-2019; (2) Untuk menganalisis ketimpangan pendapatan antar kabupaten/kota yang terjadi di Provinsi Sulawesi Selatan pada periode tahun 2005-2019; (3) menganalisis berapa besar pengaruh pertumbuhan ekonomi dan disparitas pendapatan tehadap kesejahteraan antar daerah kabupaten/kota di Provinsi Sulawesi Selatan periode tahun 2005-2019. Penelitian ini menggunakan data sekunder dengan sampel selama lima belas tahun dari tahun 2005 sampai tahun 2019. Data dianalisisdengan menggunakan program Eviews 10. Hasil penelitian menunjukkan bahwa : (1) beberapa kabupaten/kota memiliki potensi sebagai daerah maju dan tumbuh cepat, daerah maju tapi tertekan, daerah berkembang cepat dan daerah relatif tertinggal ; (2) ketimpangan pendapatan antar daerah kabupaten/kota di Provinsi Sulawesi Selatan berada pada kondisi rendah; (3) pertumbuhan ekonomi dan disparitas pendapatan berpengaruh negatif dan signifikan terhadap kesejahteraan antar daerah kabupaten/kota di Provinsi Sulawesi Selatan. Hal ini berarti bahwa pertumbuhan ekonomi dan disparitas pertumbuhan berpengaruh terhadap kesejahteraan masyarakat antar daerah kabupaten/kota di Provinsi Sulawesi Selatan.
\end{abstract}

Kata Kunci: Pertumbuhan Ekonomi, Disparitas Pendapatan, Kesejahteraan Masyarakat.

\section{Pendahuluan}

Pada sebuah Negara pasti tidak akan terlepas dari aktivitas-aktivitas perekonomian. Aktivitas perekonomian ini terjadi dalam setiap bentuk aktivitas kehidupan dan terjadi pada semua kalangan masyarakat, baik masyarakat menengah kebawah maupun pada masyarakat kalangan atas. Terlebih lagi dalam pelaksanaannya pada sebuah negara yang sedang berkembang seperti Indonesia. Indonesia merupakan daerah kepulauan yang mempunyai ribuan pulau dan mempunyai 34 provinsi. Masing-masing daerah mempunyai perbedaan ciri khas tersendiri meliputi sumberdaya alam, ekonomi, sosial budaya, adat-istiadat, jumlah dan kepadatan penduduk, mutu sumberdaya manusia, letak geografis, serta sarana dan prasarana yang tersedia disetiap daerah. Perbedaan karakteristik tersebut berhubungan pada kemampuan tumbuh masing-masing daerah, sehingga membuat pembangunan disebagian daerah tumbuh lebih cepat daripada pembangunan daerah lainnya. Oleh karena itu kebijakan pembangunan dilakukan untuk mencapai pertumbuhan ekonomi yang tinggi dengan cara memanfaatkan potensi dan sumberdaya yang ada dan berbeda-beda bagi masing-masing daerah. Proses tersebut dilakukan agar pembangunan dapat dirasakan secara lebih merata. Untuk itu perhatian pemerintah harus tertuju pada semua daerah tanpa ada perlakuan khusus pada daerah tertentu saja.

Pembangunan memiliki tujuan untuk menciptakan kesejahteraan masyarakat.Kesejahteraan masyarakat dapat dilihat dari meningkatnya pertumbuhan ekonomi dan meratanya distribusi pendapatan (Arsyad, 2010:11). Selama kurun waktu yang cukup panjang, pembangunan nasional telah menghasilkan berbagai kemajuan yang cukup berarti, namun sekaligus juga mewariskan berbagai permasalahan yang mendesak untuk ditangani, diantaranya masih terdapatnya disparitas 
atau ketimpangan antar daerah. Indikator keberhasilan pembangunan suatu daerah bisa dilihat laju pertumbuhan ekonominya. Oleh sebab itu, setiap daerah selalu menetapkan target laju pertumbuhan yang tinggi didalam perencanaan dan tujuan pembangunan daerahnya. Pertumbuhan ekonomi yang tinggi dan berkelanjutan merupakan kondisi utama bagi kelangsungan pembangunan ekonomi. Karena penduduk bertambah terus, maka dibutuhkan penambahan pendapatan setiap tahunnya. Hal ini dapat terpenuhi lewat peningkatan output secara agregat baik barang maupun jasa atau Produk Domestik Bruto (PDB) setiap tahunnya. Jadi, menurut ekonomi makro, pengertian pertumbuhan ekonomi merupakan penambahan PDB yang berarti juga penambahan pendapatan nasional (Tambunan, 2001). Kebijakan otonomi daerah merupakan sarana untuk menciptakan pembangunan yang lebih baik, karena kebijakan ini akan mampu meningkatkan pertumbuhan ekonomi dan kesejahteraan masyarakat, dimana pemerintah daerah akan lebih efisien dalam pengelolaan sumber daya yang tersedia pada masing-masing daerah dan penyediaan barang-barang publik untuk memperlancar kegiatan perekonomian. Otonomi daerah juga di maksudkan sebagai upaya dalam mengatasi ketimpangan yang terjadi antar daerah.

Berdasarkan data Badan Pusat Statistik Sulsel, secara umum PDRB Provinsi Sulawesi Selatan atas dasar harga konstan dari tahun 2005 hingga tahun 2019 mengalami peningkatan secara signifikan. Tahun 2005 PDRB Provinsi Sulawesi Selatan sebersar 36.421,79 Milliar Rupiah yang kemudian meningkat menjadi 330.605,2 Milliar Rupiah pada tahun 2019. Meningkatnya PDRB Provinsi Sulawesi Selatan disebabkan karena nilai tambah pada masing-masing sektor ekonomi meningkat ditandai dengan produktivitas masyarakat pada masing-masing sektor meningkat. Meskipun PDRB Provinsi Sulawesi Selatan cendrung meningkat tiap tahunnya, namun tidak menutup kemungkinan timbulnya permasalahan mengenai pemerataan distribusi pendapatan. Pemerataan distribusi pendapatan merupakan hal yang perlu diperhatikan dalam pembangunan daerah. Menurut Patta (2012), ketidakmerataan distribusi pendapatan akan berdampak buruk terhadap pertumbuhan ekonomi dan kemudian akan berdampak buruk juga terhadap kesejahteraan masyarakat suatu wilayah. Sedangkan berdasarkan data Bank Indonesia, laju pertumbuhan ekonomi Provinsi Sulawesi Selatan sangat tinggi dan mengalahkan laju pertumbuhan ekonomi daerah lainnya, bahkan melebihi pertumbuhan ekonomi nasional. Pertumbuhan ekonomi Provinsi Sulawesi Selatan yang tinggi ditopang oleh konsumsi rumah tangga dan investasi (dengan indikator pembentukan modal tetap bruto, PMTB).

Selain itu, berdasarkan data Bank Indonesia PDRB Perkapita Provinsi Sulawesi Selatan secara signifikan mengalami peningkatan. Pada tahun 2005 PDRB perkapita Provinsi Sulawesi Selatan sebesar 6,89 Juta Rupiah dan meningkat pada tahun 2019 sebesar 57,03 Juta Rupiah, peningkatan PDRB Perkapita Provinsi Sulawesi Selatan beriringan dengan peningkatan jumlah penduduk yang pada tahun 2005 hanya sebanyak 7.709.155 Jiwa dan mengalami peningkatan di tahun 2019 sebanyak 8.851.240 Jiwa. Ketidakmerataan yang menyebabkan ketimpangan merupakan masalah yang harus diselesaikan. Apabila ketimpangan semakin besar maka akan menimbulkan terjadinya konflik dan meningkatkan angka kriminalitas, sehingga apabila hal tersebut dibiarkan terus menerus bisa menyebabkan ketidakstabilan didalam suatu perekonomian. Oleh karena itu penelitian ini ditujukan untuk mengetahui seberapa besar ketimpangan antar kabupaten/kota di Propinsi Sulawesi Selatan. Berdasarkan uraian dari latar belakang diatas, maka yang menjadi masalah pokok pada penelitian ini adalah:

Tabel 1: Rumusan dan Tujuan Penelitian

\begin{tabular}{|c|c|}
\hline Rumusan Masalah & Tujuan Penelitian \\
\hline $\begin{array}{l}\text { 1. Bagaimana klasifikasi masing-masing daerah } \\
\text { kabupaten/kota di Provinsi Sulawesi Selatan } \\
\text { periode tahun 2005-2019 berdasarkan Tipologi } \\
\text { Klassen? }\end{array}$ & $\begin{array}{llr}\text { 1. } & \begin{array}{l}\text { Menganalisis } \\
\text { ekonomi }\end{array} \text { klasifikasi } & \text { pertumbuhan } \\
\text { kabupaten/kota di Provinsi Sulawesi Selatan } & \text { daerah } \\
\text { periode tahun 2005-2019. }\end{array}$ \\
\hline $\begin{array}{l}\text { 2. Berapa besar ketimpangan pendapatan } \\
\text { daerah antar kabupaten/kota di Provinsi } \\
\text { Sulawesi Selatan pada periode tahun 2005- } \\
\text { 2019? }\end{array}$ & $\begin{array}{l}\text { 2. Menganalisis ketimpangan pendapatan antar } \\
\text { kabupaten/kota yang terjadi di Provinsi } \\
\text { Sulawesi Selatan pada periode tahun 2005- } \\
2019 \text {. }\end{array}$ \\
\hline $\begin{array}{l}\text { 3. Berapa besar pengaruh pertumbuhan } \\
\text { ekonomi dan disparitas pendapatan tehadap } \\
\text { kesejahteraan antar daerah kabupaten/kota di } \\
\text { Provinsi Sulawesi Selatan pada tahun 2005- } \\
\text { 2019? }\end{array}$ & $\begin{array}{l}\text { Menganalisis berapa besar pengaruh } \\
\text { pertumbuhan ekonomi dan disparitas } \\
\text { pendapatan tehadap kesejahteraan antar } \\
\text { daerah kabupaten/kota di Provinsi Sulawesi } \\
\text { Selatan periode tahun 2005-2019. }\end{array}$ \\
\hline
\end{tabular}


Penelitian ini bermanfaat baik secara teoritis dan praktis sebagai berikut:

1. Secara teoritis, penelitian memberikan sumbangan pengembangan keilmuan dalam bidang Ekonomi khususnya tentang pertumbuhan ekonomi dan disparitas pendapatan terhadap kesejahteraan antar daerah kabupaten/kota di Provinsi Sulawesi Selatan. Diharapkan dapat.

2. Secara praktis: memberikan kontribusi baik berupa masukan dan pertimbangan bagi pemerintah dalam mengambil kebijakan perencanaan pembangunan daerah Provinsi Sulawesi Selatan. penelitian ini juga dapat menjadi bahan informasi dan referensi untuk penelitianpenelitian selanjutnya dalam aspek yang sama maupun aspek yang terkait.

\section{Tinjauan Pustaka}

\section{A. Pertumbuhan Ekonomi}

Pembangunan ekonomi merupakan salah satu sasaran pembangunan. Pembangunan dalam arti luas mencakup aspek kehidupan baik ideologi, politik, sosial budaya, pertahanan dan keamanan dan lain sebagainya. Pembangunan ekonomi adalah usaha-usaha untuk meningkatkan taraf hidup suatu bangsa yang sering kali dengan pendapatan riil perkapita (Irawan dan Suparmoko, 1997:5). Selanjutnya, pembangunan ekonomi perlu dipandang sebagai kenaikan dalam pendapatan perkapita, karena kenaikan merupakan penerimaan dan timbulnya dalam kesejahteraan ekonomi masyarakat. Laju pembangunan ekonomi suatu negara diukur dengan menggunakan tingkat pertumbuhan GDP/GNP (Arsyad, 1997). Pembangunan ekonomi daerah adalah suatu proses di mana pemerintah daerah dan masyarakatnya mengelola sumber daya yang ada dan membentuk suatu pola kemitraan antara pemerintah daerah dengan sektor swasta untuk menciptakan suatu lapangan pekerjaan baru dan merangsang perkembangan kegiatan ekonomi (pertumbuhan ekonomi) dalam wilayah tersebut (Arsyad, 1999). Tolak ukur keberhasilan pembangunan dapat dilihat dari pertumbuhan ekonomi, struktur ekonomi, dan semakin kecilnya ketimpangan pendapatan antar penduduk, antar daerah, antar sektor.

Pertumbuhan ekonomi tercapai bilamana terdapat peningkatan perbandingan antara input dan output yang lebih besar serta adanya perkembangan ekonomi. Perkembangan ekonomi berarti adanya peningkatan produktivitas dan pertambahan Gross Domestic Produk (Hasibuan,1987:14). Selain itu pertumbuhan ekonomi diartikan sebagai kenaikan Gross Domestic Produk (GDP) tanpa memandang apakah kenaikan itu lebih besar atau lebih kecil dari tingkat pertumbuhan penduduk atau apakah perubahan ekonomi terjadi atau tidak (Arsyad,1999:13). Menurut Tambunan (2012,h.33) bahwa pertumbuhan ekonomi yang tinggi dan berkelanjutan merupakan kondisi utama atau suatu keharusan bagi kelangsungan pembangunan ekonomi dan peningkatan kesejahteraan. Pertumbuhan ekonomi merupakan perkembangan fisikal produksi barang dan jasa yang berlaku di suatu negara (Sukirno, 2011,h.423). Salah satu indikator pertumbuhan ekonomi adalah Produk Domestik Bruto (PDB), untuk tingkat daerah adalah Produk Domestik Regional Bruto (PDRB). Produk Domestik Regional Bruto adalah jumlah nilai tambah bruto (gross value added) yang timbul dari seluruh sektor perekonomian di suatu wilayah/daerah. Tarigan (2004,h.18).

Peroux dalam Arsyad, mengemukakan sebuah teori Pusat Pertumbuhan (Pole Growth) merupakan teori yang menjadi dasar dari strategi kebijakan pembangunan industri daerah yang banyak dipakai oleh berbagai negara dewasa ini. Pertumbuhan tidak muncul diberbagai daerah pada waktu bersamaan, pertumbuhan hanya terjadi dibeberapa tempat yang disebut pusat pertumbuhan dengan intensitas yang berbeda. Pada intinya dalam teori ini industri unggulan yang merupakan penggerak dalam pembangunan ekonomi daerah. Selanjutnya muncul daerah yang relatif maju akan mempengaruhi daerah-daerah yang relatif pasif dalam industri (Arsyad, 1999). Adanya pertumbuhan ekonomi sangat penting karena dapat mempengaruhi hal-hal berikut: (1) Pertumbuhan Ekonomi dan Peningkatan Kesejahteraan Rakyat, dalam literatur ekonomi makro, tingkat kesejahteraan tersebut diukur dengan PDB perkapita. Makin tinggi PDB per kapita, makin sejahtera masyarakat. Agar PDB per kapita terus meningkat, maka perekonomian harus terus bertumbuh dan harus lebih tinggi dari pada tingkat pertambahan penduduk. Jika pertambahan penduduk suatu negara adalah $2 \%$ per tahun, maka pertumbuhan PDB harus lebih besar dari $2 \%$ per tahun.

(2) Pertumbuhan Ekonomi dan Kesempatan Kerja, manusia adalah salah satu faktor produksi terpenting dalam proses produksi, maka dapat dikatakan kesempatan kerja akan meningkat apabila output meningkat. Hubungan antara kesempatan kerja dan output dapat dilihat berdasarkan rasio 
kesempatan kerja output dan angka elastisitas kesempatan kerja. (3) Pertumbuhan Ekonomi dan Perbaikan Distribusi Pendapatan, distribusi pendapatan yang baik adalah yang makin merata. Tetapi tanpa adanya pertumbuhan ekonomi, yang terjadi adalah pemerataan kemiskinan. Pertumbuhan ekonomi hanya akan menghasilkan perbaikan distribusi pendapatan bila memenuhi setidak-tidaknya dua syarat, yaitu memperluas kesempatan kerja, maka akses rakyat untuk memperoleh penghasilan makin besar. (4) Persiapan Bagi Tahapan Kemajuan Selanjutnya, suatu bangsa, terutama suatu perekonomian, dapat diumpamakan sebagai manusia, yang tidak dapat menjadi besar dan dewasa dalam tempo semalam. Bahkan waktu yang dibutuhkan untuk mendewasakan sebuah perekonomian jauh lebih lama dibanding waktu yang dibutuhkan manusia untuk menjadi dewasa. Pertumbuhan ekonomi merupakan tangga untuk mencapai tahapan kemajuan selanjutnya. Sebab, sebuah perekonomian yang mampu terus menerus bertumbuh dalam jangka panjang, umumnya telah memiliki kemampuan untuk menjadi modern. Untuk menunjang pertumbuhan jangka panjang, yang dibutuhkan bukan saja tenaga kerja, bahkan bahan baku dan teknologi, melainkan juga kelembagaankelembagaan ekonomi dan sosial yang modern. Kelembagaan-kelembagaan tersebut misalnya pasar, keuntungan, uang, hak milik, kepastian hukum dan demokrasi.

Terdapat beberapa jenis Teori Pertumbuhan Ekonomi yaitu Teori Pertumbuhan Ekonomi Historis, Teori Pertumbuhan Klasik, Teori Pertumbuhan Neoklasik, Teori Harrod-Domar dalam Sistem Regional, Teori Pertumbuhan Ekonomi Inklusif. (1) Teori Pertumbuhan Ekonomi Historis yang dikemukakan oleh Winner Sombart (1863-1947), pertumbuhan ekonomi suatu bangsa dapat dibagi menjadi tiga tingkatan yaitu masa perekonomian tertutup, masa kerajinan dan pertukangan, serta masa kapitalis. Adapun menurut Friendrich List (1789-1846), pertumbuhan ekonomi suatu bangsa dapat dibagi menjadi empat tahap yaitu masa berburu dan pengembaraan, masa berternak dan bertani, masa bertani dan kerajinan, serta masa kerajinan, industry, dan perdagangan. Sedangkan menurut Karl Butcher (1847-1930), pertumbuhan ekonomi suatu bangsa dapat dibedakan menjadi empat tingkatan yaitu masa rumah tangga tertutup, rumah tangga kota, rumah tangga bangsa, dan rumah tangga dunia. (2) Teori Pertumbuhan Klasik, Teori ekonomi klasik menciptakan sistem ekonomi pasar bebas yang akan menciptakan efisiensi, membawa ekonomi kepada kondisi full employment dan menjamin pertumbuhan ekonomi sampai tercapai posisi stasioner. Pemerintah tidak perlu terlalu mencampuri urusan perekonomian, hal yang perlu dilakukan pemerintah daerah adalah memberi kebebasan kepada setiap orang/badan untuk berusaha, tidak membuat peraturan yang menghambat pergerakan orang dan barang, menjaga keamanan dan ketertiban sehingga relatif aman untuk berusaha, menyediakan berbagai fasilitas sarana dan prasarana sehingga pengusaha dapat beroperasi dengan efisien, dengan demikian pertumbuhan ekonomi daerah akan tercapai.

Teori Pertumbuhan Klasik terdiri atas Teori Adam Smith dan Teori David Richardo. Inti dari dari proses pertumbuhan ekonomi menurut Adam Smith dibedakan menjadi dua aspek utama pertumbuhan ekonomi yaitu pertumbuhan output (GDP) total dan pertumbuhan penduduk. Smith mengemukakan bahwa sumber daya alam yang tesedia merupakan wadah yang paling mendasar dari kegiatan produksi masyarakat. Jumlah sumber daya alam yang tersedia merupakan "batas maksimum" bagi pertumbuhan suatu perekonomian. Sumber daya belum digunakan sepenuhnya maka jumlah penduduk dan stok modal yang ada yang memegang peranan dalam pertumbuhan output. Pertumbuhan output tersebut akan berhenti jika semua sumberdaya alam tersebut telah digunakan sepenuhnya. Sumber daya manusia (jumlah penduduk) mempunyai peranan yang pasif dalam proses pertumbuhan output. Jumlah penduduk akan menyesuaikan diri dengan kebutuhan akan tenaga kerja dari suatu masyarakat. Stok modal, menurut Smith merupakan unsur produksi yang secara aktif menentukan tingkat output. Peranan sangat sentral dalam proses pertumbuhan output. Jumlah dan tingkat pertumbuhan output tergantung pada laju pertumbuhan stok modal (sampai batas maksimum dari sumber daya alam). Sedangkan garis besar Teori David Richardo tentang proses pertumbuhan dan kesimpulannya tidak jauh berbeda dengan teori Adam Smith. Tema dari proses pertumbuhan ekonomi masih pada perpacuan antara laju pertumbuhan penduduk dan laju pertumbuhan output. Ricardo juga menganggap bahwa jumlah faktor produksi tanah (sumber daya alam) tidak bisa bertambah, akhirnya menjadi faktor pembatas dalam proses pertumbuhan suatu masyarakat.

(3) Teori Pertumbuhan Neoklasik terdiri dari Teori Solow-Swan, menjelaskan bahwa adanya pertumbuhan yang mantap disebabkan kemungkinan substitusi antara modal $(\mathrm{K})$ dan tenaga kerja (L), serta dimasukkannya unsur kemajuan teknologi (T). Menurut model pertumbuhan ini, pertumbuhan output selalu bersumber dari satu atau lebih dari 3 faktor berikut : kenaikan kualitas 
dan kuantitas tenaga kerja (melalui pertambahan jumlah penduduk dan perbaikan pendidikan), perubahan modal (melalui tabungan dan investasi), serta penyempurnaan teknologi. (4) Teori Harrod-Domar dalam Sistem Regional merupakan teori berdasarkan pada asumsi antara lain perekonomian bersifat tertutup, hasrat menabung adalah konstan, proses produksi memiliki koefisien yang tetap, tingkat pertumbuhan angkatan kerja adalah konstan dan sama dengan tingkat pertumbuhan. Menurut teori ini, pertumbuhan yang mantap tergantung pada apakah arus modal dan tenaga kerja dapat bergerak searah secara seimbang, akan tetapi dapat juga pincang diakibatkan daerah yang pertumbuhannya tinggi akan menarik modal dan tenaga kerja dari daerah lain yang pertumbuhannya rendah sehingga yang maju semakin maju dan yang terbelakang semakin ketinggalan.

(5) Teori Pertumbuhan Ekonomi Inklusif, Pertumbuhan merupakan syarat penting bagi terciptanya pertumbuhan inklusif. Pertumbuhan inklusif dapat didefinisikan sebagai pertumbuhan yang tidak mendiskriminasikan dan mampu menjamin pemerataan akses pertumbuhan sekaligus sebagai pertumbuhan yang mampu menurunkan kelompok yang tidak memperoleh keuntungan dari pertumbuhan (mengurangi disparitas antar kelompok). UNDP memberikan definisi mengenai pertumbuhan inklusif berdasarkan sisi produksi dan pendapatan GDP (Gross Domestic Product), yaitu proses dan hasil pertumbuhan dimana semua pihak dapat berpartisipasi dan memperoleh manfaat yang sama dari pertumbuhan tersebut. Dengan demikian pertumbuhan inklusif merepresentasikan pemerataan. Konsep lain mengenai pertumbuhan inklusif dinyatakan dalam analisis yang dilakukan oleh Rusastra (2011) menyatakan bahwa pertumbuhan inklusif dapat dikatakan sebagai pertumbuhan yang mampu mensinergikan pertumbuhan ekonomi, peningkatan kesempatan kerja, dan pengentasan kemiskinan.

Pengertian pertumbuhan inklusif yang berhubungan dekat dengan konsep kemiskinan didukung oleh Habito (2009). Menurut kesimpulannya, pertumbuhan inklusif didefinisikan sebagai pertumbuhan GDP yang dapat menurunkan kemiskinan. Habito juga menjelaskan bahwa struktur perekonomian dan komposisi sektoral dalam pertumbuhan ekonomi telah diyakini sebagai faktor penting untuk mencapai pertumbuhan inklusif, dengan pernyataan umum bahwa pertumbuhan yang lebih kuat pada struktur pertanian akan mempercepat penurunan kemiskinan. Penekanan pada sektor pertanian ini wajar bila mengingat bahwa peran sektor pertanian terutama dalam penyerapan tenaga kerja di negara berkembang sangat besar. Selain fokus akan kondisi sektor perekonomian, Habito memandang investasi pada fasilitas publik seperti kesehatan, pendidikan dan perumahan sangat penting untuk mencapai pertumbuhan inklusif.

Min Tang (2008) memberikan perhatian terhadap persoalan kemiskinan dalam kaitannya dengan pertumbuhan inklusif dengan berangkat dari persoalan distribusi pendapatan. Ia mengamati bahwa selama beberapa dekade, banyak negara berkembang yang memiliki pertumbuhan ekonomi yang luar biasa. Sementara itu, distribusi pendapatan semakin memburuk dengan derajat yang berbeda-beda antar Negara. Beragam ukuran dan elemen dinyatakan turut memengaruhi apakah pertumbuhan dapat dikatakan inklusif. Ukuran yang paling penting adalah apakah pertumbuhan memiliki dampak terhadap peningkatan kesejahteraan orang miskin. Orang miskin, yang merupakan pihak dengan posisi paling tidak menguntungkan dalam pembangunan, memiliki kesulitan untuk memperoleh manfaat dari hasil pembangunan. Karena itu, meningkatkan kualitas hidup masyarakat miskin merupakan prioritas utama dalam agenda pertumbuhan ekonomi, tetapi terbukti sangat sulit untuk dicapai. Pertumbuhan inklusif sangat sering disamakan dengan inklusifitas pro poor, dengan demikian pertumbuhan yang tidak pro poor sudah pasti tidak inklusif (Kakwani, Khander, dan Son, 2004; dalam Min Tang, 2008).

Persoalan ketimpangan tidak luput menjadi perhatian dalam pembahasan mengenai pertumbuhan inklusif. Ali (2007) menyatakan bahwa pertumbuhan inklusif yang fokus pada percepatan perluasan kesempatan dan akses terhadap sumberdaya ekonomi bagi seluruh pelaku ekonomi, termasuk kelompok yang kurang diuntungkan, adalah syarat penting tetapi belum cukup untuk menurunkan ketimpangan pendapatan. Ketimpangan telah meningkat, tetapi hal ini bukan berarti bahwa orang kaya semakin kaya sedangkan orang miskin semakin miskin. Melainkan kekayaan orang kaya meningkat jauh lebih cepat dari pada orang miskin. Dengan melihat pada persoalan ketimpangan yang terjadi, Ali memberi kesimpulan bahwa faktor kunci yang bertanggung jawab atas peningkatan ketimpangan terlihat beragam dalam pertumbuhan. Tiga dimensi dalam perbedaan pertumbuhan terutama berkenaan dengan perbedaan pengukuran ketimpangan di berbagai bagian daerah. Yang pertama, pertumbuhan telah berbeda antar daerah di suatu negara 
(misalnya antar provinsi). Kedua, pertumbuhan berbeda antar kota dan desa. Dan yang terakhir, pertumbuhan berbeda antar rumah tangga, sehingga pendapatan masyarakat kelas atas tumbuh lebih cepat dari pada masyarakat kelas menengah atau dibawahnya.

Faktor-faktor seperti ketimpangan, kemiskinan, masalah sektoral dan tenaga kerja seringkali disebutkan dalam uraian mengenai berbagai konsep pertumbuhan inklusif. Ianchovichina dan Lundstrom (2009) memberikan pendapat yang sedikit berbeda, dimana keduanya memperhatikan kembali persoalan ukuran pertumbuhan. Ianchovichina dan Lundstrom menyatakan bahwa pertumbuhan inklusif berkaitan dengan memperbesar ukuran perekonomian dan bukan hanya fokus pada masalah distribusi sumber daya. Pertumbuhan Inklusif seringkali dikaitkan pula dengan pertumbuhan berkelanjutan merupakan konsep sederhana namun kompleks, sehingga pengertian keberlanjutanpun sangat multidimensi dan multiinterpretasi. Menurut Heal (1998), konsep keberlanjutan ini paling tidak mengandung dua dimensi: Pertama adalah dimensi waktu karena keberlanjutan tidak lain menyangkut apa yang akan terjadi di masa yang akan datang. Kedua adalah dimensi interaksi antara sistem ekonomi dan sumber daya alam dan lingkungan. Adanya multidimensi dan multi-interpretasi ini, maka para ahli sepakat untuk sementara mengadopsi pengertian yang telah disepakati oleh komisi Brundtland yang menyatakan bahwa "Pembangunan berkelanjutan adalah pembangunan yang memenuhi kebutuhan generasi saat ini tanpa mengurangi kemampuan generasi mendatang untuk memenuhi kebutuhan mereka." (ADB, 1990).

Dengan melihat komponen antar waktu yang menjadi indikator pertumbuhan berkelanjutan, maka dapat dikatakan bahwa pertumbuhan yang berkelanjutan adalah pertumbuhan inklusif namun pertumbuhan inklusif belum tentu berkelanjutan. Berbagai konsep yang ditawarkan untuk merumuskan pertumbuhan inklusif memiliki pandangan masing-masing mengenai bagaimana seharusnya pertumbuhan dapat bekerja dalam perekonomian. Pertumbuhan inklusif dapat dikatakan sebagai ukuran apakah pertumbuhan ekonomi suatu Negara merupakan pertumbuhan yang berkualitas. Definisi pertumbuhan inklusif dalam penelitian ini merupakan gabungan dari beragam konsep yang telah diuraikan sebelumnya. Dengan demikian, pertumbuhan ekonomi disebut inklusif apabila pertumbuhan tersebut mampu menurunkan kemiskinan, menurunkan ketimpangan distribusi pendapatan, dan menyerap lebih banyak tenaga kerja.

Ali dan Son (2007) telah merumuskan salah satu pendekatan untuk mengukur pertumbuhan inklusif. Dalam konteks ini, pertumbuhan inklusif tergantung pada dua faktor: (i) rata-rata kesempatan yang tersedia untuk penduduk, dan (ii) bagaimana peluang dibagi di antara populasi. Menurut Ali dan Son (2007), fungsi peluang sosial memberikan bobot yang lebih besar kepada peluang yang dinikmati oleh orang miskin: semakin miskin, maka bobotnya semakin besar. Skema pembobotan akan memastikan bahwa peluang yang diciptakan untuk orang miskin lebih penting daripada yang dibuat untuk mereka yang tidak miskin, yaitu jika kesempatan yang dinikmati oleh seseorang dipindahkan kepada orang miskin dalam masyarakat, maka peluang sosial harus meningkat, sehingga membuat pertumbuhan menjadi lebih inklusif.

Pertumbuhan dikatakan inklusif jika peluang sosial dapat tersebar pada seluruh populasi. Bagaimana peluang dapat tersebar dalam masyarakat menurut Ali dan Son (2007) dapat digambarkan dalam kurva yang disebut sebagai kurva peluang : semakin tinggi kurva, semakin besar fungsi peluang sosial. Dengan demikian pertumbuhan akan inklusif jika kurva peluang bergeser ke atas pada semua titik. Jika kurva peluang secara keseluruhan bergeser ke atas, maka artinya setiap orang dalam masyarakat, termasuk orang miskin, menikmati peningkatan peluang dan karenanya bisa disebut suatu proses pertumbuhan yang inklusif. Kemiringan pada kurva peluang sosial menunjukkan bagaimana peluang didistribusikan dalam masyarakat. Jika kurva peluang memiliki kemiringan negatif, maka dapat dikatakan bahwa kesempatan yang tersedia untuk orang miskin lebih daripada yang tersedia untuk yang tidak miskin (yaitu, peluang didistribusikan secara merata). Demikian pula, jika kurva memilki kemiringan positif, maka artinya peluang didistribusikan secara tidak adil (antipoor). Salah satu bentuk sederhana fungsi peluang sosial yang diajukan Ali dan Son (2007) dapat diperoleh dengan menghitung indeks dari daerah di bawah kurva peluang seperti yang dinyatakan pada persamaan berikut ini :

$$
\overline{\mathrm{y}} *=\int_{0}^{1} \overline{\mathrm{y}} p d p
$$

Persamaan 1 dinamakan dengan index peluang (OI, Opportunity Index). Semakin besar $\bar{y}^{*}$, maka akan semakin besar peluang yang tersedia untuk populasi. Dengan demikian tujuan utama model yang dibangun disini adalah untuk memaksimumkan nilai $\bar{y}^{*}$. Jika setiap orang dalam populasi 
menikmati kesempatan yang sama, maka dapat ditunjukkan bahwa $\bar{y}^{*}$ akan sama dengan $\bar{y}$. Dengan demikian, penyimpangan $\bar{y}^{*}$ dari $\bar{y}$ memberikan indikasi tentang bagaimana peluang tersebar di seluruh populasi. Jika $\bar{y}^{*}$ lebih besar dari $\bar{y}$, maka peluang terdistribusi secara merata (pro-poor). Demikian pula, jika $\bar{y}^{*}$ kurang dari $\bar{y}$, maka peluang yang tidak adil didistribusikan (antipoor). Berdasarkan uraian tersebut, maka indeks pemerataan peluang (EIO, Equity Index of Opportunity) dirumuskan sebagai berikut :

$$
\varphi=\frac{\overline{\mathrm{y}} *}{\overline{\mathrm{y}}}
$$

yang berarti bahwa peluang secara adil (tidak adil) didistribusikan jika $\varphi$ adalah lebih besar (kurang) dari 1. Dari (2), ditentukan bahwa :

$$
\overline{\mathrm{y}} *=\varphi \overline{\mathrm{y}}
$$

yang menunjukkan bahwa OI merupakan produk EIO dan tingkat rata-rata peluang yang tersedia bagi populasi. Untuk mencapai pertumbuhan yang inklusif, maka $\bar{y}^{*}$ harus ditingkatkan, hal ini dapat dicapai dengan: (i) meningkatkan tingkat peluang $\bar{y}$, (ii) meningkatkan indeks ekuitas peluang $\varphi$, atau (iii) meningkatkan keduanya. Untuk memahami dinamika pertumbuhan inklusif, maka Ali dan Son (2007) mengajukan rumusan berikut :

$$
d \overline{\mathrm{y}} *=\varphi d \overline{\mathrm{y}}+\overline{\mathrm{y}} d \varphi
$$

Dimana dȳ mengukur perubahan derajat inklusifitas pertumbuhan. Pertumbuhan menjadi lebih inklusif ketika dy $\bar{y}^{*}>0$. Bagian pertama di sebelah kanan persamaan (4) adalah kontribusi yang diberikan oleh kenaikan rata-rata peluang sosial terhadap inklusifitas pertumbuhan ketika peluang relatif tidak berubah; bagian kedua dari persamaan menunjukkan kontribusi perubahan distribusi ketika peluang rata-rata tidak berubah.

Selain dengan fungsi peluang sosial yang diajukan Ali dan Son, pendekatan lain dapat digunakan untuk menganalisis dan mengukur pertumbuhan inklusif. Salah satunya adalah yang dilakukan oleh Ianchovichina dan Lundstrom (2009), yang mengadopsi kerangka Hausmann, Rodrik, and Velasco (HRV) (2005). Kerangka HRV hanyalah satu di antara banyak pendekatan untuk analisis pertumbuhan yang inklusif. Hal ini sangat relevan dalam kasus di mana tingkat pendapatan rendah, pertumbuhan lambat dan investasi rendah. Dengan latar belakang demikian, kerangka HRV merupakan kerangka kerja yang tepat untuk mempelajari isu-isu pertumbuhan inklusif karena pertumbuhan adalah pendorong utama pengurangan kemiskinan. Menurut pendekatan ini, jika seseorang mendefinisikan pendapatan dari setiap individu i sebagai:

$$
y_{\mathrm{i}} \equiv \mathrm{w}_{1} E_{1} \omega_{\mathrm{i} 1}+\cdots+\mathrm{w}_{\mathrm{j}} E_{\mathrm{j}} \omega_{\mathrm{ij}}
$$

Dimana $w_{j}$ adalah harga, $E_{j}$ adalah sumbangan dari masing-masing faktor $j$ perekonomian, dan $\omega_{i j}$ - bagian dari faktor j yang dimiliki oleh individu i. Kemudian, dengan membagi setiap sisi dengan pendapatan total dan menjumlahkan seluruh kelompok tertentu individu, misalnya kelompok miskin, diperoleh:

$$
\psi_{p} \equiv \lambda_{1} \omega_{P 1}+\ldots+\lambda_{1} \omega_{P j}
$$

Dimana $\psi p$ adalah bagian dari pendapatan yang diterima oleh kelompok kepentingan, $\lambda_{j}$ adalah bagian dari faktor $\mathrm{i}$ di total pendapatan, dan $\omega_{P j}$ adalah bagian dari faktor $\mathrm{j}$ yang dimiliki oleh kelompok. Identitas ini menunjukkan variabel yang memengaruhi bagian pendapatan dari kelompok yang menjadi fokus. Dalam pendekatan yang digunakan Ianchovichina dan Lundstrom (2009), Instrumen utama untuk pertumbuhan yang berkelanjutan dan inklusif yaitu pekerjaan yang produktif. Oleh karena itu, pertumbuhan yang inklusif tidak hanya tentang pertumbuhan lapangan kerja, tetapi juga tentang pertumbuhan produktivitas. Kemampuan individu untuk dapat dipekerjakan secara produktif tergantung pada peluang untuk memanfaatkan sepenuhnya sumber daya yang tersedia karena ekonomi berkembang dari waktu ke waktu. Alternatif lain untuk mengukur pertumbuhan inklusif dirumuskan oleh Klasen (2010). Menurutnya, pendekatan yang sederhana untuk memeriksa pertumbuhan yang inklusif diperlukan. Dalam merumuskan metode pengukuran untuk pertumbuhan inklusif, Klasen mengadaptasi metode dari penelitian-penelitian propoor growth. Secara khusus, adaptasi dilakukan dari penelitian Kakwani dan Son (2008) mengenai konsep "poverty-equivalent growth rate" yang mendefinisikan pertumbuhan inklusif sebagai pertumbuhan untuk kelompok kurang beruntung.

Manfaat pertumbuhan bisa dihitung dengan menggunakan metode PEGR yang merupakan salah satu metode yang digunakan untuk mengukur manfaat pertumbuhan ekonomi bagi penduduk 
miskin. Dalam penghitungan PEGR sendiri, terdapat 2 metode, yaitu dengan menggunakan teknik analisis secara ex ante dan post ante. Metode penghitungan PEGR dengan menggunakan teknik analisis secara ex-ante diterapkan berdasarkan asumsi bahwa perubahan ketidakmerataan pendapatan hanya berlangsung dengan cara terjadi pergeseran secara proporsional dan konstan di semua titik pada kurva Lorenz. Padahal pergeseran kurva Lorenz dapat disebabkan banyak hal, sehingga metode penghitungan PEGR secara $e x$-ante ini tidak mungkin untuk dilakukan. Metode penghitungan PEGR dengan menggunakan teknik analisis ex-post dilakukan untuk mengatasi permasalahan penghitungan secara ex-ante, yaitu dengan cara membandingkan keadaan kemiskinan, distribusi pendapatan (kurva Lorenz) dan rata-rata pendapatan penduduk pada awal periode dengan keadaan pada akhir periode. Misalkan ukuran kemiskinan merupakan fungsi dari garis kemiskinan $\mathrm{z}$, rata-rata pendapatan $\mu$, dan kurva Lorenz $L(p)$, yang dituliskan sebagai berikut:

$$
P=P(z, \mu, L(p))
$$

Jika ukuran kemiskinan yang digunakan adalah :

$$
P_{\alpha}=\frac{1}{n} \sum_{i=1}^{q}\left[\frac{z-y_{i}}{z}\right]^{\alpha}
$$

Dimana $a=0,1,2$ dan $y_{i}=$ pendapatan penduduk ke-i dan $q=$ jumlah penduduk miskin. Maka perubahan persentase penduduk miskin pada periode 1 dan periode 2 dapat dituliskan sebagai berikut :

$P_{12}=P_{2}-P_{1}=\operatorname{Ln}\left[P\left(\mathrm{z}, \mu_{2}, L_{2}(p)\right]-\operatorname{Ln}\left[P\left(\mathrm{z}, \mu_{1}, L_{1}(p)\right]\right.\right.$

Nilai $P_{12}$ ini masih mengandung komponen pertumbuhan dan komponen distribusi. Misalkan $\mu_{1}$ dan $\mu_{2}$ merupakan rata-rata pendapatan penduduk pada periode 1 dan periode 2 , maka pertumbuhan pendapatan penduduk $(\hat{Y})$ dapat dirumuskan sebagai berikut:

$$
\hat{\mathrm{Y}}=\operatorname{Ln}\left(\mu_{2}\right)-\operatorname{Ln}\left(\mu_{1}\right)
$$

Total elastisitas kemiskinan $(\delta)$ dapat didekomposisi menjadi elastisitas kemiskinan yang berkaitan dengan pertumbuhan $(\eta)$ dan elastisitas kemiskinan yang berkaitan dengan ketidakmerataan $(\zeta)$. Persamaan untuk total elastisitas $(\delta)$ sebagai berikut:

$\hat{\delta}=\left(\operatorname{Ln}\left[P\left(z, \mu_{2}, L_{2}(p)\right]-\operatorname{Ln}\left[P\left(z, \mu_{1}, L_{1}(p)\right]\right) / \hat{Y}\right.\right.$

dan $\widehat{\delta}=\hat{\eta}+\hat{\zeta}$

dimana elastisitas kemiskinan terhadap pertumbuhan dirumuskan sebagai berikut :

$\hat{\mathrm{n}}=\frac{1}{2 y}\left[\operatorname{Ln}\left(P\left(z, \mu_{2}, L_{1}(p)\right)-\operatorname{Ln}\left(P\left(z, \mu_{1}, L_{1}(p)\right)+\operatorname{Ln}\left(P\left(z, \mu_{2}, L_{2}(p)\right)-\operatorname{Ln}\left(P\left(z, \mu_{1}, L_{2}(p)\right)\right]\right.\right.\right.\right.$

dan elastisitas kemiskinan terhadap ketidakmerataan dirumuskan sebagai berikut :

$\hat{\zeta}=\frac{1}{2 y}\left[\operatorname{Ln}\left(P\left(z, \mu_{1}, L_{2}(p)\right)-\operatorname{Ln}\left(P\left(z, \mu_{1}, L_{1}(p)\right)+\operatorname{Ln}\left(P\left(z, \mu_{2}, L_{2}(p)\right)-\operatorname{Ln}\left(P\left(z, \mu_{2}, L_{1}(p)\right)\right]\right.\right.\right.\right.$

Berdasarkan rumusan (11) hingga rumusan (14) tersebut, maka nilai PEGR dapat dirumuskan sebagai berikut :

$$
\operatorname{PEGR}=\hat{\mathrm{Y}}^{*}=(\hat{\delta} / \hat{\mathrm{n}}) \hat{\mathrm{Y}}
$$

Nilai PEGR dapat dikelompokkan sebagai berikut:

1. Jika $\hat{Y}^{*}=\hat{Y}$ maka artinya pertumbuhan bersifat netral, setiap orang menerima manfaat yang sama secara proporsional dari pertumbuhan.

2. Jika $\hat{Y}^{*}>\hat{Y}$ berarti pertumbuhan bersifat pro poor growth, penduduk miskin lebih banyak menerima manfaat dari pertumbuhan.

3. Jika $0<\hat{Y}^{*}<\hat{Y}$ artinya pertumbuhan belum bersifat pro poor growth, manfaat pertumbuhan lebih banyak diterima penduduk tidak miskin (ketidakmerataan meningkat) tetapi masih terjadi pengurangan Kemiskinan.

4. Jika $\hat{Y}^{*}<0$ berarti pertumbuhan bersifat anti pro poor growth atau manfaat pertumbuhan yang dinikmati penduduk tidak miskin, kemiskinan meningkat. 
Dengan mengadopsi uraian mengenai konsep PEGR, maka pertumbuhan inklusif dapat diukur dengan rumusan berikut :

Dimana :

$$
I G_{i j}=\frac{G_{i j}}{\overline{G_{J}}} * \bar{G}_{J}
$$

$\mathrm{IG}_{\mathrm{ij}}=$ Koefisien pertumbuhan inklusif

$G_{i j}=$ Pertumbuhan kelompok i dalam kaitannya dengan indikator $j$

$\mathrm{G}_{\mathrm{j}}=$ Pertumbuhan indikator $\mathrm{j}$

Dalam hal ini i mengacu pada kelompok kurang beruntung tertentu dan j mengacu pada indikator yang bersangkutan (misalnya, pertumbuhan pendapatan atau ekspansi dalam pendidikan).

Faktor-Faktor Yang Mempengaruhi Pertumbuhan Ekonomi suatu negara tergantung pada sumber alamnya, sumber manusia, modal, usaha, teknologi dan sebagainya. Semua itu merupakan faktor ekonomi. Para ahli ekonomi menganggap faktor produksi sebagai kekuatan utama yang mempengaruhi pertumbuhan. Laju pertumbuhan ekonomi jatuh atau bangunnya merupakan konseskuensi dari perubahan yang terjadi di dalam faktor produksi tersebut. Beberapa faktor ekonomi yang turut mempengaruhi pertumbuhan ekonomi : (1) Sumber Alam, adalah segala kekayaan yang dimiliki suatu daerah berupa tumbuh-tumbuhan dan berbagai jenis tanaman, dengan adanya kekayaan alam ini maka akan menjadi nilai tambah disuatu wilayah dan dapat dioptimalkan menjadi keunggulan wilayah tersebut. (2) Akumulasi Modal, adalah segala yang berkaitan dengan nilai dalam hal ini investasi, dengan investasi maka suatu wilayah akan meningkatkan outputnya dalam arti peningkatan produksi dan akan menyerap tenaga kerja ekonomipun menjadi membaik. (3) Organisasi, adalah sekumpulan orang yang memiliki tujuan yang sama secara bersama-sama dengan adanya organisasi maka akan mensinergikan anatar satu organisasi dengan yang lain dan akan menghasilkan kemajuan. (4) Teknologi, adalah penunjang dari yang biasanya dapat dilakukan oleh manusia menjadi dapat dilakukan oleh alat atau robot sehingga memudahkan pekerjaan manusia, dengan adanya teknologi maka peningkatan hasil produksi akan meningkat dan optimalisasi dari pertumbuhan ekonomi. (5) Pembagian Kerja dan Skala Produksi, skala produksi adalah peningkatan jumlah kapasitas produksi suatu wilayah, suatu wilayah dikatakan unggul apabila memiliki produksi yang berkualitas. Semakin banyak jumlah produksi maka semakin banyak output yang dihasilkan otomatis keuangan daerah meningkat.

\section{B. Disparitas Pendapatan}

Pengertian dari ketimpangan pembangunan atau disparitas adalah perbedaan pembangunan antar suatu wilayah dengan wilayah lainnya secara vertikal dan horizontal yang menyebabkan disparitas atau ketidak pemerataan pembangunan. Ketimpangan pembangunan antar daerah dengan pusat dan antar daerah satu dengan daerah lain merupakan suatu hal yang wajar, karena adanya perbedaan dalam sumber daya dan awal pelaksanaan pembangunan antar daerah (Sjafrizal, 2008). Menurut Kamus Besar Bahasa Indonesia, ketimpangan merupakan hal yang tidak sebagaimana mestinya seperti tidak adil, tidak beres. Sedangkan, pendapatan adalah seluruh penghasilan yang diterima baik sektor formal maupun non formal yang terhitung dalam jangka waktu tertentu. Disparitas pendapatan atau yang sering dikenal dengan ketimpangan pendapatan adalah suatu kondisi dimana distribusi pendapatan yang diterima masyarakat tidak merata. Ketimpangan ditentukan oleh tingkat pembangunan, heterogenitas etnis, ketimpangan juga berkaitan dengan kediktatoran dan pemerintah yang gagal menghargai property rights.

Ketimpangan yang paling lazim dibicarakan adalah ketimpangan ekonomi. Dalam ketimpangan ada ketimpangan pembangunan ekonomi antar daerah secara absolut maupun ketimpangan relatif antara potensi dan tingkat kesejahteraan tersebut dapat menimbulkan masalah dalam hubungan antar daerah. Filsafah pembangunan ekonomi yang dianut pemerintah jelas tidak bermaksud membatasi arus modal (bahkan yang terbang ke luar negeri saja hampir tidak dibatasi). Arus modal mempunyai logika sendiri untuk berakumulasi di lokasi-lokasi yang mempunyai tingkat pertumbuhan yang lebih tinggi, dan tingkat resiko yang lebih rendah. Sehingga tidak dapat dihindari jika arus modal lebih terkonsentrasi di daerah-daerah kaya sumber daya alam dan kota-kota besar yang sarana dan prasarananya lebih lengkap yang mengakibatkan jumlah penduduk yang menganggur di Provinsi yang berkembang akan meningkat. Pendapatan perkapita rata-rata suatu daerah dapat di 
sederhanakan menjadi Produk Domestik Regional Bruto (PDRB) dibagi dengan jumlah penduduk. Cara lain yang bisa digunakan adalah dengan mendasarkan kepada pendapatan personal yang didekati dengan pendekatan konsumsi (Sjafrizal, 2008).

\section{a) Konsep Ketimpangan}

Ketimpangan adalah suatu keadaan yang tidak merata antara satu dengan yang lain. Ketimpangan dalam pembangunan juga masih terjadi pada saat ini antara Negara maju dan Negara berkembang, Negara maju memiliki pengetahuan yang tinggi dari segi SDM dan bisa mengolah SDA yang dimiliki secara efektif dan efisien sedangkan Negara berkembang yang belum memiliki SDM yang baik tidak mengolah SDA secara efektif. Hal ini sangatlah menguntungkan bagi Negara maju sehingga terjadi perbedaan pendapatan yang cukup tinggi antara Negara maju dan Negara berkembang. Teori ketimpangan pendapataan yang dikemukakan oleh Arsyad (1992) bahwa penghapusan kemiskinan dan berkembang ketidakmerataan distiribusi pendapatan merupakan inti permasalahan pembangunan. Murty (dalam Yuzea, 2006) mengemukakan bahwa kesenjangan regional oleh diartikan sebagai ketidakseimbangan pertumbuhan antar sektor primer, sekunder, tersier atau sektor sosial di suatu negara, distrik, atau tempat di mana peristiwa itu terjadi. Pada negara maju atau berkembang, negara pertanian atau industri, negara besar atau kecil, mempunyai wilayah yang maju dan tertinggal secara ekonomi. Hal itu penting untuk menghubungkan pola pembangunan ekonomi regional dengan beragam variabel fisik dan sosial ekonomi untuk mengidentifikasikan variabel mana yang mempunyai pengaruh terbanyak terhadap pola pertumbuhan.

Kesenjangan tidak berlaku di semua wilayah dengan kekuatan (tingkatan) yang sama, tetap terdapat aspek-aspek umum yang dapat memberikan beberapa generalisasi, penyebab utama kesenjangan adalah: (a) Faktor Geografis, suatu wilayah yang sangat luas, distribusi dari sumberdaya nasional, sumber energi, sumberdaya pertanian, topografi, iklim dan curah hujan tidak akan merata. Apabila faktor-faktor lain sama, maka kondisi geografi yang lebih baik akan menyebabkan suatu wilayah berkembang lebih baik. (b) Faktor Historis, tingkat pembangunan suatu masyarakat juga bergantung pada masa yang lalu untuk menyiapkan masa depan. Bentuk organisasi ekonomi yang hidup di masa lalu menjadi alasan penting yang dihubungkan dengan isu insentif, untuk pekerja dan pengusaha. Sistem feodal memberikan sangat sedikit insentif untuk bekerja keras. Sistem industri dimana pekerja merasa tereksploitasi, bekerja tanpa istirahat, suatu perencanaan dan sistem yang membatasi akan memberi sedikit insentif dan menyebabkan pembangunan terhambat. (c) Faktor Politik, ketidakstabilan politik dapat menjadi penghambat pembangunan yang sangat kuat. Jika pemerintah stabil tapi lemah, korupsi dan ketidak mampuan untuk mengalahkan sikap mementingkan diri sendiri dan menolak tekanan atau kontrol sosial akan menggagalkan tujuan dari kebijakan pembangunan. Kondisi politik disetiap wilayah tidak sama. (d) Faktor Kebijakan Pemerintah, hampir semua negara kaya sedang diterapkan konsep Negara kesejahteraan (welfare of state). Di negara tersebut, kebijakan pemerintah mulai diarahkan secara langsung pada pemertaan regional yang lebih besar. Kekuatan pasar yang menghasilkan efek "backwash" dihilangkan, sementara yang menghasilkan efek menyebar didukung sementara di negara-negara miskin, kebijakan yang demikian masih sangat sedikit. (e) Faktor Administrasi (birokrasi), faktor administrasi yang efisien atau tidak efisien berpengaruh dalam menambah kesenjangan antar wilayah. Pemerintah dalam menjalankan fungsinya membutuhkan administrator yang jujur, terdidik, terlatih dan efisien karena birokrasi yang efisien akan berhasil dalam pembangunan regional dan sebaliknya. (f) Faktor Sosial, banyak faktor sosial yang menjadi penghalang dalam pembangunan. Penduduk di wilayah yang belum berkembang memiliki lembaga dan keinginan (attitude) yang kondusif untuk pembangunan ekonomi. Penduduk dari wilayah yang lebih maju memiliki kelembagaan dan keinginan yang kondusif untuk pembangunan. (g) Faktor Ekonomi, penyebab secara ekonomis seperti perbedaanperbedaan dalam faktor produksi, proses kumulatif dari berbagai faktor, siklus kemiskinan yang buruk, kekuatan pasar yang bebas dan efek "backwash" dan efek menyebar (spread) dan pasar tidak sempurna, berlangsung dan menambah kesenjangan dalam pembangunan ekonomi.

b) Faktor Penyebab Ketimpangan Ekonomi

1. Penyebab Ketimpangan Pendapatan di Negara Berkembang.

Irma Adelman dan Cynthia Taft Morris tahun 1973 (Lincolin Arsyad, 1997) menyatakan bahwa faktor penyebab ketimpangan pendapatan di negara sedang berkembang yaitu pertumbuhan 
penduduk yang tinggi yang mengakibatkan turunnya pendapatan perkapita, inflasi, ketidakmerataan pembangunan antar daerah, investasi yang sangat banyak dalam proyek-proyek yang padat modal (capital intensive), rendahnya mobilitas sosial, pelaksanaan kebijakan industri subtitusi impor yang menyebabkan kenaikan harga-harga barang hasil industri untuk melindungi golongan kapitalis, memburuknya nilai tukar bagi mata uang negara sedang berkembang dalam perdagangan dengan negara maju sebagai akibat ketidakelastisan barang-barang ekspor dari negara sedang berkembang, hancurnya industri-industri kerajinan rakyat seperti pertukangan, industri rumah tangga dan lainlain.

\section{Penyebab Ketimpangan Ekonomi Antar Wilayah}

Ketimpangan ekonomi antar wilayah merupakan ketidaks eimbangan pertumbuhan ekonomi di suatu wilayah. Ketimpangan ekonomi antar wilayah merupakan aspek yang umum terjadi dalam kegiatan ekonomi suatu daerah. Ketimpangan muncul karena adanya perbedaan kandungan sumberdaya alam dan perbedaan kondisi demografi yang terdapat pada masing-masing wilayah. Sehingga kemampuan suatu daerah dalam proses pembangunan juga menjadi berbeda. Oleh karena itu, pada setiap daerah terdapat wilayah maju dan wilayah terbelakang. Ketimpangan juga memberikan implikasi terhadap tingkat kesejahteraan masyarakat antar wilayah yang akan mempengaruhi formulasi kebijakan pembangunan wilayah yang dilakukan oleh pemerintah (Sjafrizal, 1997). Adanya analisis ini, akan dapat dijelaskan secara empirik unsur penyebab terjadinya ketimpangan ekonomi wilayah tersebut. Penyebab ketimpangan ekonomi antar wilayah yaitu perbedaan kandungan sumber daya alam, perbedaan kondisi demografis, kurang lancarnya mobilitas barang dan jasa, konsentrasi kegiatan ekonomi wilayah, alokasi dana pembangunan antar wilayah

c) Penanggulangan Ketimpangan Pembangunan Wilayah

Kebijakan dan upaya untuk menanggulangi ketimpangan ekonomi antar wilayah sangat ditentukan oleh faktor yang menentukannya, yang dapat dilakukan dalam rangka mengurangi ketimpangan ekonomi antar daerah dalam suatu negara atau wilayah yaitu penyebaran pembangunan prasarana perhubungan, mendorong transmigrasi dan migrasi spontan, pengembangan pendidikan antar wilayah, pengembangan pusat pertumbuhan, pelaksanaan otonomi daerah.

\section{d) Mengukur Ketimpangan}

Distribusi pendapatan nasional mencerminkan merata atau timpangnya pembagian hasil pembangunan suatu negara dikalangan penduduknya. Terdapat berbagai kriteria atau tolak ukur untuk menilai kemerataan distribusi yang dimaksud, berikut cara mengukur ketimpangan:

\section{Kurva Lorenz.}

Kurva Lorenz menggambarkan distribusi kumulatif pendapatan nasional di kalangan lapisanlapisan penduduk secara kumulatif. Kurva ini terletak di sebuah bujur sangkar yang sisi tegaknya melambangkan persentase kumulatif pendapatan nasional, sedangkan sisi dasarnya mewakili persentase kumulatif penduduk. Kurvanya sendiri ditempatkan pada diagonal utama bujur sangkar tersebut.

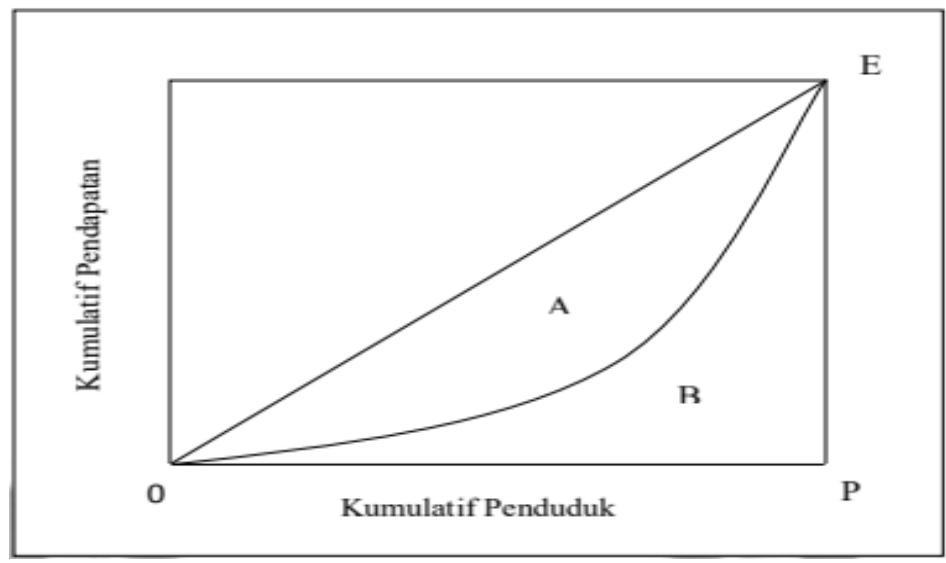

Gambar 1: Kurva Lorenz dan indeks Gini 
Kurva Lorenz yang semakin dekat ke diagonal (semakin lurus) menyiratkan distribusi pendapatan nasional yang semakin merata. Sebaliknya, jika kurva Lorenz semakin jauh dari diagonal (semakin lengkung), maka ia mencerminkan keadaan yang semakin buruk, distribusi pendapatan nasional semakin timpang atau tidak merata.

\section{Indeks Gini.}

Indeks Gini atau lengkapnya Corrado Gini merumuskan suatu ukuran untuk menghitung tingkat ketimpangan pendapatan personal secara agregatif yang diterima di atas tingkat tertentu. Hasil temuannya sering disebut sebagai gini coefficient atau indeks gini. Koefisien gini adalah ukuran ketimpangan agregat dan bisa memiliki nilai berapapun, berkisar dari angka 0 (kemerataan sempurna) hingga 1 (ketimpangan sempurna), yang menjelaskan kadar kemerataan pendapatan. Koefisien yang semakin mendekati 0 berarti distribusi pendapatan semakin merata, sebaliknya koefisien yang semakin mendekati 1 berarti distribusi pendapatan semakin timpang. Koefisien Gini bagi Negara-negara yang distribusi pendapatannya sangat timpang berada di antara 0,50 dan 0,70, sedangkan bagi Negara-negara yang distribusi pendapatannya yang relatif merata memiliki koefisien Gini antara 0,20 dan 0,35.

Angka rasio Gini dapat ditaksir secara visual langsung dari kurva Lorenz, yaitu perbandingan luas area yang terletak diantara kurva Lorenz dan diagonal terhadap luas area segitiga OBC. Semakin melengkung Kurva Lorenz, akan semakin luas yang dibagi rasio Gininya akan semakin besar, menyiratkan distribusi pendapatan yang semakin timpang. Ukuran ketidaksamaan digunakan untuk menggunakan ukuran ini diperkenalkan oleh Williamson (1965) perhitungan nilai ini didasarkan pada variasi indeks memodifikasi perhitungan ini untuk menimbang proporsi penduduk wilayah tersebut. Berbeda dengan indeks Gini yang menghitung nilai dari seluruh distribusi pendapatan rumah tangga di suatu wilayah atau negara, indeks Williamson dapat melihat besarnya ketimpangan distribusi pendapatan antar daerah dalam suatu wilayah. Semakin besar angka indeks Williamson, semakin besar derajat ketidaksetaraan. Indeks ini dapat dihitung menggunakan rumus:

\section{Dimana:}

$$
\mathrm{IW}=\frac{\sqrt{\left(Y i-\hat{\mathrm{Y}} \frac{\hat{\mathrm{fi}}}{n}\right.}}{\hat{\mathrm{Y}}}
$$

IW: Indeks kesenjangan pendapatan

$\mathrm{f}_{\mathrm{i}}$ : Total populasi setiap provinsi i

n: Jumlah populasi nasional

$Y_{i}:$ PDB masing-masing provinsi i

$\hat{Y}$ : Rata-rata PDB

Adanya heterogenitas dan beragamnya karakteristik suatu wilayah menyebabkan kecenderungan terjadinya ketimpangan antardaerah dan antarsektor ekonomi suatu daerah. Kesenjangan/ketimpangan daerah merupakan konsekuensi logis pembangunan dan merupakan suatu tahap perubahan dalam pembangunan itu sendiri (Kuncoro 2004: 133). Menurut Williamson yang meneliti hubungan antara disparitas regional dan tingkat pembangunan ekonomi dengan menggunakan data ekonomi negara yang sudah maju dan yang sedang berkembang. Ditemukan bahwa selama tahap awal pembangunan, disparitas regional menjadi lebih besar dan pembangunan terkonsentrasi di daerah-daerah tertentu. Pada tahap yang lebih "matang", dilihat dari pertumbuhan ekonomi, tampak adanya keseimbangan antardaerah dan disparitas berkurang dengan signifikan (Kuncoro 2004: 134). Menurut Basri (dalam Sasana, 2009) distribusi pendapatan nasional menunjukkan merata atau tidaknya pembagian hasil pembangunan suatu negara di kalangan penduduknya. Misalnya untuk kasus di Indonesia, menurut Sakamoto (2006) distribusi pendapatan antar provinsi atau antar kabupaten/kota menunjukkan kesenjangan pendapatan yang cukup tinggi. Faktor-faktor yang diduga menyebabkan terjadinya perbedaan pendapatan antar wilayah ini adalah kepemilikan sumber daya alam, ketersediaan infrastruktur, dan kualitas sumber daya manusia (Arsyad, 2010:288).

e) Hubungan antara pertumbuhan ekonomi dengan ketimpangan pembangunan

Perbedaan tingkat kemajuan ekonomi antar daerah yang berlebihan mengakibatkan pengaruh yang merugikan (backwash effects) mendominasi pengaruh yang menguntungkan (spread effects) hal ini menyebabkan ketidakseimbangan. Pelaku-pelaku yang mempunyai kekuatan di pasar secara normal 
akan cenderung meningkat bukannya menurun, sehingga mengakibatkan kesenjangan antardaerah (Arsyad, 2004). Berikut dua teori ketimpangan wilayah, yaitu tricking downpolarization effect; serta backwash-spread effect : (a) Tricking Downpolarization Effect, Albert O. Hirscman (1970), dalam tulisanya yang berjudul interregional and international transmission of economic growth, membedakan daerah di suatu negara menjadi daerah kaya dan daerah miskin. Jika perbedaan antara kedua daerah tersebut semakin menyempit berarti terjadi imbas yang baik (tricking downpolarization effect). Perbedaan antara kedua daerah tersebut semakin melebar berarti terjadi proses pengkutuban (polarization effect). (b) Backwash-Spread Effect, Myrdal (dalam Jhingan, 1990) menyatakan bahwa ketimpangan regional dalam suatu negara berakar pada dasar non ekonomi.

Myrdal menyatakan bahwa pertumbuhan suatu wilayah akan mempengaruhi wilayah disekitarnya melalui dampak balik (backwash effect) dan dampak sebar (spread effect). Dampak balik (backwash effect) terjadi saat pertumbuhan ekonomi di suatu wilayah (misal: wilayah A) mengakibatkan berpindahnya sumber daya (tenaga kerja, modal, dll) dari wilayah sekitarnya. Wilayah A (yang awalnya merupakan wilayah yang lebih maju dibandingkan wilayah B), akan semakin maju dan wilayah B akan semakin tertinggal. Dampak sebar (spread effect) terjadi saat pertumbuhan ekonomi di suatu wilayah (misal: wilayah A) mengakibatkan pertumbuhan wilayah disekitarnya (misal: wilayah B), yang memproduksi bahan mentah untuk keperluan industri yang sedang tumbuh di sentra-sentra tersebut, dan sentra-sentra yang mempunyai industri barang-barang konsumsi akan terangsang. Mrydal menyimpulkan bahwa ketimpangan wilayah diakibtakan oleh lemahnya dampak sebar dan kuatnya dampak balik (Arsyad, 1997).

\section{Kesejahteraan}

Kesejahteraan sosial dapat di definisikan sebagai suatu kondisi kehidupan individu dan masyarakat yang sesuai dengan standar kelayakan hidup yang dipersepsi masyarakat (Swasono, 2004). Tingkat kelayakan hidup dipahami secara relatif oleh berbagai kalangan dan latar belakang budaya, mengingat tingkat kelayakan ditentukan oleh persepsi normative suatu masyarakat atas kondisi sosial, material, dan psikologis tertentu. Menurut Undang-undang No. 11 Tahun 2009, tentang Kesejahteraan Masyarakt, kesejahteraan masyarakat adalah kondisi terpenuhinya kebutuhan material, spiritual, dan sosial warga Negara agar dapat hidup layak dan mampu mengembangkan diri, sehingga dapat melaksanakan fungsi sosialnya. Dari Undang-undang di atas dapat kita cermati bahwa ukuran tingkat kesejahteraan dapat di nilai dari kemampuan seorang individu atau kelompok dalam usahanya memenuhi kebutuhan material dan spiritualnya. Kebutuhan material ini dapat kita hubungkan dengan pendapatan yang nantinya akan mewujudkan kebutuhan akan pangan, sandang, papan dan kesehatan. Kemudian kebutuhan spiritual kita hubungkan dengan pendidikan, kemudian keamanan dan ketentraman hidup.

Kesejahteraan merupakan titik ukur bagi suatu masyarakat bahwa telah berada pada kondisi sejahtera. Kesejahteraan tersebut dapat diukur dari kesehatan, keadaan ekonomi, kebahagiaan dan kualitas hidup rakyat (Segel dan Bruzy, 1998:8). Menurut Sinungan, (2008:9) peningkatan produktivitas sama dengan meningkatkan masukan tenaga kerja dimana masukan tersebut diartikan sebagai pendapatan, karena pendapatan dapat menghasilkan rupiah untuk mencukupi kebutuhan hidup sehari-hari, maka produktivitas dikatakan memiliki pengaruh langsung terhadap peningkatan kesejahteraan keluarga melalui pendapatan. Pengukuran produktivitas dilihat dari bentuk pengorbanan dan hasil pekerja. Upah merupakan hasil pengorbanan pekerja dalam bentuk rupiah, sedangkan jam dan hari kerja merupakan bentuk pengorbanan yang telah dilakukan seorang pekerja. Kesejahteraan selalu dikaitkan dengan materi, dimana semakin tinggi produktivitas maka pendapatan yang dihasilkan pun akan semakin tinggi. Ukuran tingkat kesejahteraan lainnya juga dapat dilihat dari non materi seperti yang dikatakan oleh Pratama dan Mandala, (2008:242) melalui tingkat pendidikan, kesehatan dan gizi, kebebasan memilih pekerjaan dan jaminan masa depan yang lebih baik.

Kesejahteraan ekonomi merupakan cabang ilmu ekonomi yang menggunakan teknik ekonomi mikro untuk menentukan secara serempak efisiensi alokasi dari ekonomi makro dan akibat distribusi pendapatan yang saling berhubungan. Kegiatan ekonomi merupakan kegiatan yang tidak terlepas dari pasar. Pada dasarnya kegiatan ekonomi lebih mementingkan sebuah keuntungan bagi pelaku ekonomi dari pasar tersebut. Sehingga sangat sulit dalam menemukan ekonomi yang dapat menyejahterakan, apabila dilihat dari mekanisme pasar yang ada. Keadaan pasar yang begitu kompetitif untuk mencari keuntungan, merupakan salah satu hal yang menjadi penghambat untuk 
menuju kesejahteraan. Kompetitif dalam pasar merupakan hal yang sangat wajar, karena persaingan menjadi sesuatu yang wajib dalam mekanisme pasar. Ekonomi memiliki tugas untuk memberi prinsip yang rasional bagi bisnis sebagai kegiatan ekonomi, sehingga kegiatan ekonomi tersebut tidak hanya mengarah diri pada kebutuhan hidup manusia perorang dan jangka pendek, akan tetapi juga memberi surplus bagi kesejahteraan banyak orang dalam negara. Dalam kegiatan pasar akan banyak mempengaruhi optimal atau tidaknya kegiatan ekonomi tersebut. Kompetisi dalam pasar juga bisa menimbulkan dampak negatif untuk terwujudnya ekonomi kesejahteraan. Dimana kompetisi pasar membuat konteks sosial yang harus diperhatikan dalam pencapaian ekonomi kesejahteraan menjadi lebih sulit tercapai. Maka, perlu adanya ilmu kesejahteraan ekonomi dalam membangun suatu kegiatan ekonomi yang dapat memberikan atau menciptakan suatu kondisi yang sejahtera dalam skala bermasyarakat ataupun lingkungan keluarga.

Terdapat dua jenis kesejahteraan ekonomi, yaitu kesejahteraan ekonomi konvensional dan kesejahteraaan ekonomi syariah.

1. Kesejahteraan Ekonomi Konvensional

Kesejahteraan ekonomi konvensional hanya menekankan pada kesejahteraan material, dengan mengabaikan kesejahteraan spiritual dan moral. Dimana kesejahteraan ekonomi konvensional menggunakan dua pendekatan dalam menentukan kesejahteraan ekonomi, yaitu pendekatan NeoKlasik dan pendekatan ekonomi kesejahteraan yang baru (modern). Pendekatan Neo-Klasik berasumsi bahwa nilai guna merupakan kardinal dan konsumsi tambahan itu menyediakan peningkatan yang semakin kecil dalam nilai guna (diminishing marginal utility). Pendekatan NeoKlasik lebih lanjut berasumsi bahwa semua individu mempunyai fungsi nilai guna yang serupa, oleh karena itu hal tersebut mempunyai makna untuk membandingkan nilai guna individu dengan nilai guna milik orang lain. Oleh karena asumsi ini, hal tersebut memungkinkan untuk membangun suatu fungsi kesejahteraan sosial dengan hanya menjumlahkan seluruh fungsi nilai guna individu. Pendekatan modern perkembangan dari neo klasik dimana perpaduan antara kesejahteraan tidak dapat diukur hanya dengan materi namun non materi juga dipertimbangkan dalam menentukan sebuah kesejahteraan. Sebab kesejahteraan meliputi jasamani yang besifat materil dan rohani yang bersifat non materil.

2. Kesejahteraan Ekonomi Syariah

Kesejahteraan ekonomi syariah bertujuan mencapai kesejahteraan manusia secara menyeluruh, yaitu kesejahteraan material, kesejahteraan spiritual dan moral. Konsep ekonomi kesejahteraan syariah bukan saja berdasarkan manifestasi nilai ekonomi, tetapi juga nilai moral dan spiritual, nilai sosial dan nilai politik Islami. Dalam pandangan syariah terdapat 3 segi sudut pandang dalam memahami kesejahteraan ekonomi yakni pertama, dilihat dari pengertiannya, sejahtera sebagaimana dikemukakan dalam Kamus Besar Indonesia adalah aman, sentosa, damai, makmur, dan selamat (terlepas) dari segala macam gangguan, kesukaran, dan sebagainya. Pengertian ini sejalan dengan pengertian "Islam" yang berarti selamat, sentosa, aman, dan damai. Dari pengertiannya ini dapat dipahami bahwa masalah kesejahteraan sosial sejalan dengan misi Islam itu sendiri. Misi inilah yang sekaligus menjadi misi kerasulan Nabi Muhammad SAW, sebagaimana dinyatakan dalam ayat QS. Al-Anbiyấ' Ayat 107.

Artinya:

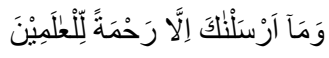
alam."

“Dan tidaklah Kami mengutus kamu (Muhammad), melainkan untuk (menjadi) rahmat bagi seluruh

Kedua, dilihat dari segi kandungannya, terlihat bahwa seluruh aspek ajaran Islam ternyata selalu terkait dengan masalah kesejahteraan sosial. Hubungan dengan Allah misalnya, harus dibarengi dengan hubungan dengan sesama manusia (hablum minallâh wa hablum minnan-nâs). Demikian pula anjuran beriman selalu diiringi dengan anjuran melakukan amal saleh, yang di dalamnya termasuk mewujudkan kesejahteraan sosial. Selanjutnya, ajaran Islam yang pokok (Rukun Islam), seperti mengucapkan dua kalimat syahadat, shalat, puasa, zakat, dan haji, sangat berkaitan dengan kesejahteraan sosial.Ketiga, upaya mewujudkan kesejahteraan sosial merupakan misi kekhalifahan yang dilakukan sejak Nabi Adam As. Sebagian pakar, sebegaimana dikemukakan H.M. Quraish Shihab dalam bukunya Wawasan Al-Quran, menyatakan bahwa kesejahteraan sosial yang didambakan Al-Quran tercermin di Surga yang dihuni oleh Adam dan isterinya sesaat sebelum mereka turun melaksanakan tugas kekhalifahan di bumi. 
Kesejahateraan sosial dalam islam adalah pilar terpenting dalam keyakinan seorang muslim adalah kepercayaan bahwa manusia diciptakan oleh Allah SWT. Ia tidak tunduk kepada siapapun kecuali kepada Allah SWT. (Q.S. Ar-Ra'du:36) dan (Q.S. Luqman: 32). Ini merupakan dasar bagi piagam kebebasan sosial Islam dari segala bentuk perbudakan. Menyangkut hal ini, Al-Qur'an dengan tegas menyatakan bahwa tujuan utama dari misi kenabian Muhammad SAW. adalah melepaskan manusia dari beban dan rantai yang membelenggunnya (Q.S. Al-A'raaf:157). Islam mengakui pandangan universal bahwa kebebasan individu merupakan bagian dari kesejahteraan yang sangat tinggi. Menyangkut masalah kesejahteraan individu dalam kaitannya dengan masyarakat.

Konsep kesejahteraan tidak dapat dipisahkan dari kualitas hidup masyarakat, dimana kualitas hidup masyarakat dapat dipengaruhi oleh kondisi sosial politik maupun ekonomi masyarakat tersebut. Disimpulkan bahwa pengertian ukuran kesejahteraan awalnya hanya diukur melalui aspek fisik dan income saja, namun berkembangnya zaman saat ini kesejahteraan diukur melalui beberapa indikator-indikator seperti kesehatan, pendidikan dan sosial ekonominya. Kesejahteraan pada intinya mencakup tiga konsepsi, yaitu: (1) Kondisi kehidupan atau keadaan sejahtera, yakni terpenuhinya kebutuhan-kebutuhan jasmaniah, rohaniah, dan sosial. (2) Institusi, arena atau bidang kegiatan yang melibatkan lembaga kesejahteraan sosial dan berbagai profesi kemanusiaan yang menyelenggarakan usaha kesejahteraan sosial dan pelayanan sosial. (3) Aktivitas, yakni suatu kegiatan-kegiatan atau usaha yang terorganisir untuk mencapai sejahtera

Indikator kesejahteraan masyarakat dalam pembangunan dapat diukur dengan pendekatan indikator moneter dan non moneter (Arsyad, 2004). Indikator moneter mengukur kesejahteraan berdasarkan pendekatan pendapatan perkapita. Sedangkan pengukuran tingkat kesejahteraan masyarakat dengan indikator non moneter mengacu pada suatu indeks yang telah dikembanghkan oleh United Nations for Development Program (UNDP) yaitu Indeks Pembangunan Manusia (Human Developmen Indeks) (Tamin, 2002). Indikator-indikator yang digunakan untuk menyusun indeks ini adalah: (1) tingkat harapan hidup; (2) tingkat melek huruf; dan (3) tingkat pendapatan riil perkapita berdasarlkan daya beli masyarakat. Selain itu aspek penting kesejahteraan masyarakat adalah terbebasnya masyarakat dari kemiskinan. Kemiskinan menjadi salah satu ukuran terpenting untuk mengetahui tingkat kesejahteraan masyarakat (Suradi, 2016).

Pengukuran kesejahteraan masyarakat dilakukan dengan tujuh indikator yaitu pendapatan perkapita, penduduk miskin, pengangguran terbuka, angka sakit, tingkat pendidikan, informasi teknologi, dan indek perumahan yang yang merupakan gabungan dari tujuh sub indikator. Daerah dengan kondisi kesejahteraan masyarakat akan ditandai dengan tingginya pendapatan perkapita, rendahnya penduduk miskin (Sutrisno, 1995), pengangguran terbuka (Simanjutak, 2002), angka sakit, dan pendidikan rendah serta tingginya akses masyarakat terhadap informasi dan teknologi. Ada beberapa indikator keluarga sejahtera berdasarkan Badan Pusat Statistik (2000), yaitu: Pendapatan, konsumsi atau pengeluaran rumah tangga, keadaan tempat tinggal, fasilitas tempat tinggal, kesehatan anggota keluarganya, kemudahan mendapatkan pelayanan kesehatan, dan kemudahan memasukkan anak kejenjang pendidikan Indikator kesejahteraan dalam masyarakat itu sendiri menurut publikasi BPS, menyarankan tujuh komponen untuk mengukur tingat kesejahteraan yaitu kependudukan, kesehatan dan gizi, pendidikan, ketenagakerjaan, taraf pola konsumsi, perumahan dan lingkungan, sosial budaya.

Dalam memahami realitas tingkat kesejahteraan, pada dasarnya terdapat beberapa faktor yang menyebabkan terjadinya kesenjangan tingkat kesejahteraan antara lain: (a) Social ekonomi rumah tangga atau masyarakat. (b) Struktur kegiatan ekonomi sektoral yang menjadi dasar kegiatan produksi rumah tangga atau masyarakat. (c) Potensi regional (sumberdaya alam, lingkungan dan insfrastruktur) yang mempengaruhi perkembangan struktur kegiatan produksi. (d) Kondisi kelembagaan yang membentuk jaringan kerja produksi dan pemasaran pada skala lokal, regional dan global. Secara lebih spesifik bahwa fungsi kesejahteraan $W$ (walfare) dengan persamaan sebagai berikut: $\mathrm{W}=\mathrm{W}(\mathrm{Y}, \mathrm{I}, \mathrm{P})$. Dimana $\mathrm{Y}$ adalah pendapatan perkapital, I adalah ketimpangan dan P adalah kemiskinan absolut. Ketiga variabel ini mempunyai signifikan yang berbeda, dan harus dipertimbangkan secara menyeluruh untuk menilai kesejahteraan negara berkembang. Berkaitan dengan fungsi persamaan kesejahteraan diatas, diasumsikan bahwa kesejahteraan sosial berhubungan positif dengan pendapatan perkapita, namun berhubungan negatif dengan kemiskinan. 
a) Produktivitas

Produktivitas pada penelitian ini lebih menspesifikkan terhadap perhitungan produktivitas tenaga kerja, dimana dari hasil produktivitas tersebut dapat menghasilkan sejumlah pendapatan untuk meningkatkan kesejahteraan. Produktivitas tenaga kerja menurut Siagian, (2002) adalah salah satu ukuran perusahaan dalam mencapai tujuan. Produktivitas adalah perbandingan antara hasil dari suatu pekerjaan karyawan dengan pengorbanan yang telah dikeluarkan. Peningkatan produktivitas kerja hanya mungkin dilakukan oleh manusia. Produktivitas tenaga kerja diperlukan untuk perhitungan seberapa besar pendapatan yang harus diterima oleh pekerja atas pengorbanan yang telah dilakukannya. Menurut Muchdarsyah Sinungan, (2008:9) peningkatan produktivitas dapat berpengaruh langsung pada standar hidup dalam meningkatkan kesejahteraan seorang pekerja. Penambahan tenaga kerja akan mendorong kenaikan upah, karena menurut Prathama dan Mandala, (2008:268) makin banyak penduduk yang berusia kerja atau usia produktif (15-64 tahun), maka makin besar tingkat konsumsi, terutama bagi sebagian besar dari mereka yang mendapat kesempatan kerja dengan upah yang wajar atau baik. Ukuran produktivitas yang paling terkenal menurut Muchdarsyah Sinungan, (2008:12) yaitu jam kerja dan hari kerja, karena produktivitas tenaga kerja dapat dihitung dengan membagi pengeluaran dengan jumlah yang digunakan atau jam-jam kerja seseorang. Mengukur produktivitas menggunakan hasil pekerjaan seseorang dalam bentuk upah dimana seberapa besar jumlah upah ditentukan oleh seberapa besar jumlah pengorbanan yang dilakukan oleh pekerja dalam bentuk jam kerja.

b) Tingkat Pendidikan

Pendidikan memiliki peran penting bagi pengembangan sumberdaya manusia yang tersedia. Bagi negara berkembang, pendidikan dasar menjadi prioritas utama untuk mengembangkan sumberdaya manusia sejak dini. Hal tersebut diungkapkan oleh Todaro, (2003:404) bahwa pendidikan memainkan peran kunci dalam membentuk kemampuan sebuah negara berkembang untuk menyerap teknologi modern dan untuk mengembangkan kapasitas pertumbuhan dan pembangunan yang berkelanjutan. Pendidikan yang digunakan dalam penelitian ini adalah pendidikan tenaga kerja, dimana pendidikan dapat menjamin masa depan yang lebih baik bagi pekerja karena tingkat pendidikan membuka peluang terhadap gaji tinggi. Seseorang yang berpendidikan tinggi akan mempengaruhi pola pikir, sikap dan perilakunya. Semakin tinggi pendidikan dan kualitas pendidikan yang lebih baik serta memiliki keterampilan yang melengkapi pendidikan formal memungkinkan mereka mendapat keuntungan yang lebih tinggi. Menurut Rozana Himaz, (19852006:3) meningkatkan akses dan kualitas pendidikan juga telah diakui bahwa tidak hanya dapat meningkatkan kesejahteraan tetapi membawa orang tersebut keluar dari kemiskinan dan mengurangi kesenjangan.

Pendidikan bagi tenaga kerja adalah salah satu usaha untuk pembagian kerja atau spesialisasi pekerja merupakan upaya untuk meningkatkan produktivitas tenaga kerja. Menurut Adam Smith (dalam Kuncoro 1997:38) spesialisasi yang dilakukan oleh pekerja didorong oleh factor-faktor yaitu peningkatan keterampilan kerja, dan penemuan mesin-mesin yang menghemat tenaga. Spesialisasi dapat meningkatkan kesejahteraan seseorang secara tidak langsung melalui pendidikan, karena sangat membantu seseorang dalam pencarian lapangan kerja seefisien mungkin. Pada umumnya di negara-negara berkembang, segenap biaya sosial dari pendidikan meningkat secara cepat seiring dengan semakin tingginya tingkat pendidikan yang ditempuh para pelajar. Hal ini dikarenakan manfaat yang diharapkan dari pendidikan yang lebih tinggi jauh lebih besar bila dibandingkan manfaat dari tingkat pendidikan yang lebih rendah. Berikut adalah sebuah ilustrasi antara biaya dan manfaat bagi tingkat pendidikan seseorang menurut Todaro, (2003:427-430) : 


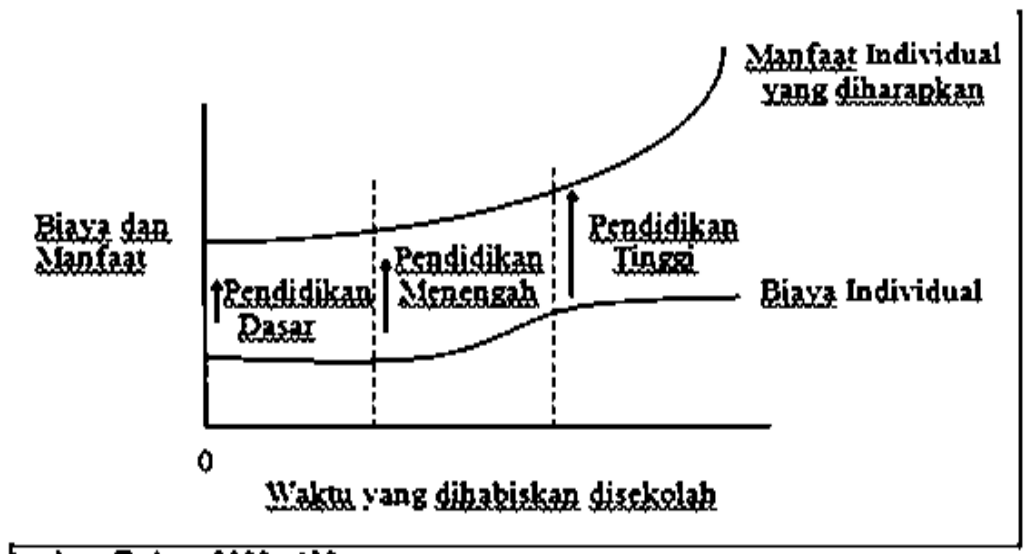

Euplex:Trdaxs $2003: 130$

\section{Gambar 2: Biaya dan Manfaat Pendidikan Bagi Individual}

Gambar tersebut menjelaskan bahwa semakin tinggi pendidikan dapat menghabiskan banyak waktu yang biaya yang harus ditempuh, namun dalam jangka panjang pendidikan yang lebih tinggi akan mendatangkan manfaat yang lebih besar dari pada pendidikan yang rendah. Pendidikan merupakan ukuran yang penting dalam menentukan pendapatan. Hal ini karena akses terhadap pekerjaan dengan gaji tinggi baik disektor pemerintahan maupun swasta tergantung dari tingginya tingkat pendidikan (Kuncoro, 1997:124). Pendidikan memiliki arti penting yaitu sebagai investasi menganggap manusia sebagai suatu bentuk modal yang pada akhirnya dapat meningkatkan kesejahteraan hidupnya dimasa yang akan datang. Investasi pendidikan memang akan mendatangkan hasil atau manfaat dalam waktu lama, karena pada saat berinvestasi, keluarga memerlukan sejumlah biaya dan waktu yang akan menghabiskan pendapatan yang diterima.

\section{Penelitian Terdahulu}

a. Endang Kusdiah Ningsih, Dwi Eka Novianty, Sri Ermeila (2019) dengan judul Pengaruh Pertumbuhan Ekonomi Terhadap Disparitas Pembangunan di Provinsi Sumatera Selatan. Hasil penelitian menyimpulkan bahwa Hasil perhitungan Indeks Williamson menujukkan bahwa tingkat ketimpangan pembangunan di propinsi Sumatera Selatan dari tahun 2010 - 2017 dan 2015-2017 masuk dalam kategori tinggi karena nilai IW >0,35. Sedangkan pada tahun 2014, ketimpangan pembangunan yang terjadi sangat tinggi karena nilai IW mendekati 1, yaitu sebesar 0.90. Hasil analisis korelasi Pearson menujukkan bahwa terdapat hubungan yang negatif antara pertumbuhan ekonomi dan ketimpangan pembangunan sebesar -0,253 dengan nilai signifikansi sebesar $0,545>0,05$. artinya peningkatan pertumbuhan ekonomi akan menyebabkan penurunan ketimpangan dalam pembangunan. Hasil ini juga membuktikan bahwah hipotesa Kuznets tentang kurva U-terbalik berlaku di propinsi Sumatera Selatan pada tahun 2010- 2017. Untuk meminimalkan dampak pembangunan ekonomi terhadap ketimpangan pembangunan maka perlu adanya program pemerataan pembangunan yang berkeadilan di semua bidang.

b. Baiq Hipziwaty, Putu Karismawan, Baiq Ismiwaty (2019) dengan judul Pertumbuhan Ekonomi, Disparitas Pendapatan, dan Kesejahteraan Kabupaten/kota di Provinsi Nusa Tenggara Barat. Kesimpulan dari penelitian ini yaitu: Pertumbuhan ekonomi Provinsi Nusa Tenggara Barat cendrung berfluktuatif yang dipengaruhi oleh naik turunnya nilai sektor ekonomi. Berfluktuatifnya pertumbuhan ekonomi disebabkan oleh naik turunya nilai berbagai sektor ekonomi yang menjadi sektor unggulan seperti sektor pertanian, konstruksi serta perdagangan besar dan eceran dan resparasi mobil dan sepeda motor. Rata-rata pertumbuhan ekonomi antar Kabupaten/Kota di Provinsi Nusa Tenggara Barat yaitu sebesar 6,0\% yang dimana masih dalam pertumbuhan ekonomi sedang. Disparitas pendapatan antar Kabupaten/Kota Provinsi Nusa Tenggara Barat yang diukur dengan indeks Williamson dalam periode 2010-2016 yang ditunjukkan oleh nilai indeks Williamson yang lebih besar dari 0, indeks Williamson memperlihatkan kencendrungan yang semakin menurun setiap tahunnya dan tergolong dalam kriteria ketimpangan sedang. Berdasarkan hasil estimasi hubungan variabel pertumbuhan ekonomi dan disparitas pendapatan terhadap kesejahteraan masyarakat Provinsi Nusa Tenggara Barat yang diukur menggunakan IPM tahun 2010-2016 menggunakan analisis regresi data panel 
dengan model Fixed Effect (FEM) sebagai model terbaik, ditemukan bahwa variabel pertumbuhan ekonomi berhubungan positif namun tidak signifikan terhadap kesejahteraan masyarakat Provinsi Nusa Tenggara Barat. Kemudian variabel disparitas pendapatan berhubungan signifikan terhadap kesejahteraan masyarakat Provinsi Nusa Tenggara Barat.

c. Riris Lastri Nababan dan Banatul Hayati (2019) dengan judul penelitian Analisis Disparitas Pendapatan dan Faktor penentu Pertumbuhan Ekonomi Provinsi-provinsi di Pulau Jawa Tahun 2011-2016. Penelitian ini menarik kesimpulan bahwa Indeks Williamson menunjukkan bahwa ketimpangan pendapatan antar provinsi di Pulau Jawa masih tinggi, yaitu dengan rata-rata senilai 0,6 yang menunjukkan bahwa Pulau Jawa memiliki ketimpangan tinggi, terlihat bahwa distribusi pendapatan tidak merata setiap tahunnya antar daerah yang ada di Pulau Jawa. Hasil kurva Lorenz dan gini rasio menunjukkan bahwa disparitas pendapatan di pulau jawa dari tahun 2011 hingga 2016 mengalami peningkatan yang ditunjukkan oleh semakin menjauhnya kurva Lorenz dari garis pemerataan. Angkatan Kerja menunjukkan pengaruh positif dan tidak signifikan terhadap pertumbuhan ekonomi hal ini berarti marginal productivity of labor di Pulau Jawa rendah sehingga tidak mempengaruhi pertumbuhan ekonomi. Rata-Rata Lama Sekolah menunjukkan bahwa rata-rata lama sekolah memiliki pengaruh positif dan signifikan terhadap pertumbuhan ekonomi. Artinya semakin lama jenjang pendidikan formal yang dilalui maka akan semakin menghasilkan tenaga kerja yang lebih produktif.

\section{E. Kerangka Konseptual}

Kerangka konsep dan hipotesis penelitian ini menggambarkan konsep yang terdiri dari variabelvariabel yang diteliti serta acuan dalam menjalankan penelitian, dapat digambarkan sebagai berikut:

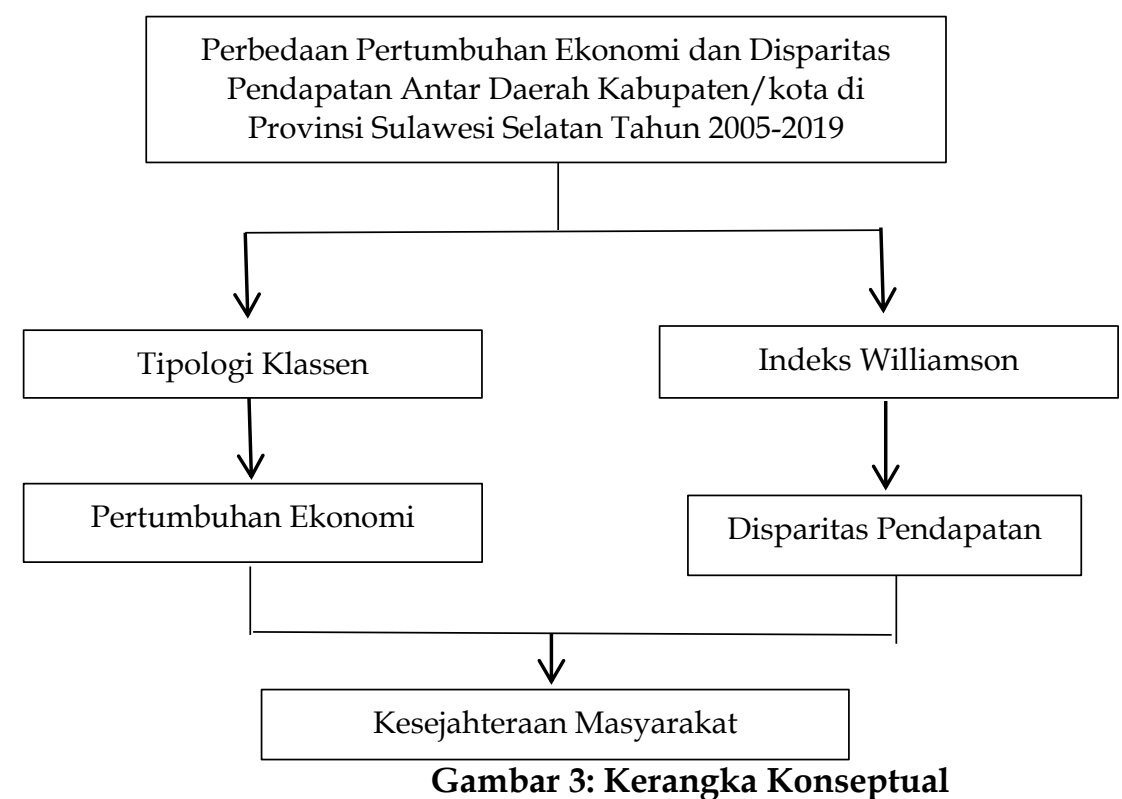

Berdasarkan rumusan masalah dan kerangka konseptual tersebut di atas, maka hipotesis, yang diajukan dalam penelitian ini adalah:

1. Diduga bahwa beberapa kabupaten memiliki potensi sebagai daerah maju dan tumbuh cepat, daerah maju tapi tertekan, daerah berkembang cepat dan daerah relatif tertinggal.

2. Diduga bahwa ketimpangan pendapatan antar daerah kabupaten/kota di Provinsi Sulawesi Selatan berada pada kondisi sedang.

3. Diduga pertumbuhan ekonomi dan disparitas pendapatan berpengaruh signifikan terhadap kesejahteraan antar daerah kabupaten/kota di Provinsi Sulawesi Selatan.

\section{Metode Penelitian}

Pendekatan penelitian yang digunakan dalam penulisan merupakan penelitian deskriptif dengan pendekatan kuantitatif. Penelitian deskriptif adalah penelitian yang berusaha untuk menuturkan pemecahan masalah yang ada sekarang berdasarkan data-data yang ada. Tujuan dari penelitian 
deskriptif ini adalah membuat deskriptif, gambaran atau lukisan secara sistematis serta hubungan antar fenomena yang diselidiki. Sedangkan yang dimaksud dengan pendekatan kuantitatif adalah pendekatan yang digunakan dalam penelitian dengan cara mengukur indikator-indikator variabel penelitian sehingga diperoleh gambaran diantara variabel-variabel tersebut. Penggunaan penelitian deskriptif-kuantitatif mendeskripsikan secara sistematis, faktual dan akurat terhadap suatu perlakuan pada wilayah tertentu mengenai hubungan sebab akibat berdasarkan pengamatan terhadap akibat yang ada. Kemudian melalui pendekatan kuantitatif dapat menduga faktor yang bisa menjadi penyebab untuk memahami dan mendeskripsikan realitas rasional sebagai realitas subjek melalui teknik analisis kuantitatif, khususnya sektor-sektor yang berpengaruh terhadap pertumbuhan ekonomi dan kesejahteraan masyarakat di Provinsi Sulawesi Selatan 2005-2019.

Penelitian ini dilakukan di wilayah Provinsi Sulawesi Selatan, dengan jangka waktu penelitian selama dua bulan, dari bulan Desember tahun 2020 sampai bulan Februari tahun 2021. Penelitian dilakukan di Provinsi Sulawesi Selatan dengan pertimbangan bahwa Provinsi Sulawesi Selatan merupakan salah satu provinsi yang sedang gencar-gencarnya melakukan pembangunan yang dimana untuk meningkatkan pertumbuhan ekonomi dan meningkatkan kesejahteraan masyarakatnya serta tersedianya data-data yang berkaitan dengan penelitian yang akan dilakukan. Adapun data yang diperoleh dalam penelitian ini bersumber dari BPS Provinsi Sulawesi Selatan. Data yang digunakan dalam penelitian ini adalah data sekunder. Data sekunder yaitu data yang diperoleh secara tidak langsung dari buku-buku referensi, jurnal ekonomi, badan pusat statistik (BPS) Provinsi Sulawesi Selatan, dan peneliti-peneliti sebelumnya yang berkaitan dengan penelitian ini. Data yang diperlukan dalam penelitian ini meliputi :

1. PDRB Provinsi Sulawesi Selatan ADHK periode tahun 2005-2019.

2. PDRB Kabupaten/Kota di Provinsi Sulawesi Selatan ADHK periode tahun 2005-2019.

3. PDRB Perkapita Provinsi Sulawesi Selatan ADHK periode tahun 2005-2019.

4. PDRB Perkapita Provinsi Sulawesi Selatan ADHK periode tahun 2005-2019.

5. Jumlah Penduduk Provinsi Sulawesi Selatan Tahun 2005-2019.

6. Jumlah Penduduk Kabupaten/Kota di Provinsi Sulawesi Selatan tahun 2005-2019.

7. Pertumbuhan Ekonomi Provinsi Sulawesi Selatan Tahun 2005-2019.

8. Pertumbuhan Ekonomi Kabupaten/Kota di Provinsi Sulawesi Selatan tahun 2005-2019.

9. Indeks Pembangunan (IPM) Provinsi Sulawesi Selatan Tahun 2005-2019.

10. Indeks Pembangunan (IPM) Kabupaten/Kota di Provinsi Sulawesi Selatan tahun 2005-2019.

Metode yang digunakan dalam pengumpulan data pada penelitian ini adalah metode Studi Pustaka, yang diperoleh dari buku-buku referensi, jurnal ekonomi, badan pusat statistik (BPS) Provinsi Sulawesi Selatan, dan peneliti-peneliti sebelumnya yang berkaitan dengan penelitian ini. Populasi adalah wilayah generalisasi yang terdiri atas obyek/subyek yang mempunyai kualitas dan karakteristik tertentu yang ditetapkan oleh peneliti untuk dipelajari dan kemudian ditarik kesimpulannya. Populasi yang diambil dalam penelitian ini adalah seluruh laporan data pertumbuhan ekonomi yang di peroleh dari badan pusat statistik (BPS) Kabupaten/kota di Provinsi Sulawesi Selatan. Sampel merupakan bagian dari poulasi yang memiliki ciri atau keadaan tertentu yang akan diteliti. Sampel merupakan anggota populasi yang dipilih dengan mengunkan teknik atau metode penentuan sampel tertentu. Sampel dalam penelitian ini yaitu jangka waktu sepuluh tahun dari tahun 2005 sampai dengan tahun 2019.

\section{Metode Analisis Data}

\section{Analisis Tipologi Klassen}

Teknik Tipologi Klassen dapat digunakan melalui dua pendekatan yang pertama adalah dengan pendekatan sektoral yang mendasarkan pengelompokan suatu sektor dengan melihat pertumbuhan dan kontribusi sektor tertentu terhadap total PDRB kabupaten/kota dan yang kedua adalah dengan pendekatan wilayah berdasarkan dua indikator utama, yaitu pertumbuhan ekonomi dan pendapatan atau produk domestik regional bruto (PDRB) per kapita daerah (Fajar,2010).

Menentukan rata-rata pertumbuhan ekonomi sebagai sumbu vertikal dan rata-rata pendapatan perkapita sebagai sumbu horizontal, daerah yang diamati dapat dibagi menjadi empat klasifikasi. Menurut Tipologi Daerah, daerah dibagi menjadi 4 klasifikasi : 
1. Kuadran I : Daerah cepat maju dan cepat tumbuh yaitu daerah Kabupaten/Kota dengan PDRB rata-rata perkapita diatas rata-rata PDRB perkapita Provinsi dan rata-rata laju pertumbuhan ekonomi di atas rata-rata laju pertumbuhan ekonomi Provinsi.

2. Kuadran II : Daerah maju tapi tertekan yaitu Kabupaten/Kota dengan rata-rata PDRB perkapita di atas PDRB perkapita Provinsi dan rata-rata laju pertumbuhan ekonomi di bawah rata-rata laju pertumbuhan ekonomi Provinsi.

3. Kuadran III : Daerah berkembang cepat yaitu Kabupaten/Kota dengan rata-rata PDRB perkapita di bawah rata-rata PDRB perkapita Provinsi dan rata-rata laju pertumbuhan ekonomi di atas rata-rata laju pertumbuhan ekonomi Provinsi.

4. Kuadran IV : Daerah relatif tertinggal yaitu Kabupaten/Kota dengan rata-rata PDRB perkapita di bawah rata-rata PDRB perkapita Provinsi dan rata-rata laju pertumbuhan ekonomi di bawah rata-rata laju pertumbuhan ekonomi Provinsi.

Tabel 2. Klasifikasi Tipologi Klassen Pendekatan Sektoral/Daerah

\begin{tabular}{|c|c|c|}
\hline PDRB perkapita (y) Laju Pertumbuhan $(\mathrm{r})$ & Yi $>\mathrm{y}$ & Yi $<\mathrm{y}$ \\
\hline $\mathrm{Ri}>\mathrm{r}$ & Kuadran I & Kuadran II \\
& Daerah maju dan Tumbuh cepat & Daerah maju tapi tertekan \\
\hline $\mathrm{Ri}<\mathrm{r}$ & Kuadran III & Kuadran IV \\
& Daerah berkembang cepat & Daerah relative tertinggal \\
\hline
\end{tabular}

Dimana:

$\mathrm{Ri}=$ laju pertumbuhan PDRB Kabupaten/Kota

Yi $=$ PDRB perkapita Kabupaten/Kota

$\mathrm{r}=$ Rata-rata laju pertumbuhan PDRB Provinsi

$y=$ Rata-rata PDRB perkapita Provinsi

\section{Indeks Williamson}

Rumus Williamson mengaitkan beberapa variabel, yakni jumlah penduduk pada suatu kota, tingkat PDRB, semuanya diasumsikan secara hierarkis. Artinya, jika yang dihitung adalah kabupaten, maka perbandingannya adalah dengan provinsi yang menaungi kabupaten tersebut. Jika yang dihitung adalah provinsi, maka perbandingannya adalah dengan angka nasional. Ukuran ketimpangan pendapatan untuk menganalisis seberapa besarnya kesenjangan antar wilayah/daerah adalah dengan melalui perhitungan indeks Williamson. Dasar perhitungannya adalah dengan menggunakan PDRB perkapita dalam kaitannya dengan jumlah penduduk perdaerah. Dapat dihitung dengan rumus berikut:

$$
\mathrm{IW}=\frac{\sqrt{\sum(Y i-\hat{Y}) 2 . f i / n}}{\hat{\mathrm{Y}}}
$$

Keterangan:

IW: Indeks kesenjangan pendapatan

$\mathrm{Y}_{\mathrm{i}}$ : PDRB per kapita kabupaten/kota ke-i

$\hat{Y}$ : Rata-rata PDB

$\mathrm{f}_{\mathrm{i}}$ : Jumlah penduduk kabupaten/kota ke-i

$\mathrm{n}$ : Jumlah populasi nasional

Besarnya IW adalah $0<$ IW $<1$

IW $=0$, berarti pembangunan wilayah sangat merata

IW $=1$, berarti pembangunan wilayah sangat tidak merata

IW $<0$, berarti pembangunan wilayah semakin mendekati merata

IW $<1$, berarti pembangunan wilayah semakin mendekati tidak merata.

\section{Analisis Regresi Data Panel}

Regresi data panel digunakan untuk menganalisis hubungan pertumbuhan ekonomi dan disparitas pendapatan anatar Kabupaten/Kota di Provinsi Sulawesi Selatan. Model penelitian yang digunakan dalam studi ini dapat menyebutkan bahwa kesejahteraan masyarakat adalah fungsi dari pertumbuhan ekonomi dan disparitas pendapatan dapat ditulis sebagai berikut: $K S J R M=f(P E, D P)$. 
Dari model ekonomi diatas kemudian ditransformasikan ke spesifikasi model ekonometrika sebagai berikut :

Keterangan :

$$
\mathrm{KSJRM}_{\mathrm{it}}=\beta_{0}+\beta_{1} \mathrm{PE}_{\mathrm{it}}+\beta_{2} \mathrm{DP}_{\mathrm{it}}+\varepsilon_{\mathrm{it}}
$$

KSJRM = Kesejahteraan Masyarakat

$\mathrm{PE} \quad=$ Pertumbuhan Ekonomi

$\mathrm{DP} \quad=$ Disparitas Pendapatan

$\beta_{0} \quad=$ Bilangan konstanta $\beta 1$

$\beta_{2} \quad=$ Koefisien masing-masing variabel

$\mathrm{i} \quad=1,2, \ldots, \mathrm{N}$ (data cross section Kabupaten/Kota di Provinsi Sulawesi Selatan)

$\mathrm{t} \quad=1,2, \ldots, \mathrm{T}$ (data time series 2010-2096)

cit $=$ error term

4. Uji Statistik

a. Uji t-statistik

Uji t-statistik merupakan pengujian variabel-variabel independen secara individu (parsial) yang dilakukan untuk mengetahui seberapa besar hubungan masing-masing variabel independen dalam mempengaruhi variabel dependen dengan anggapan variabel lain dianggap tetap atau konstan.

b. Uji F-statistik

Uji F-statistik dapat dilakukan untuk melihat bagaimana hubungan variabel independen terhadap variabel dependen secara keseluruhan atau bersama-sama (simultan). Pengujian ini bertujuan mengetahui apakah model pendugaan yang diajukan sudah layak untuk menduga parameter yang ada dalam fungsi.

c. Uji Koefisien Determinasi (R-Square)

Koefisien determinasi $\left(\mathrm{R}^{2}\right)$ pada intinya mengukur seberapa besar proporsi model dalam variasi variabel dependen mampu dijelaskan oleh variabel independen secara bersama-sama.

\section{Hasil dan Pembahasan}

5.

\section{Pertumbuhan Ekonomi}

Pertumbuhan ekonomi merupakan salah satu indikator makro untuk melihat kinerja perekonomian secara riil di suatu wilayah. Laju pertumbuhan ekonomi dihitung berdasarkan perubahan PDRB atas dasar harga konstan tahun yang bersangkutan terhadap tahun sebelumnya. Pertumbuhan ekonomi dapat dipandang sebagai pertambahan jumlah barang dan jasa yang dihasilkan oleh semua lapangan usaha kegiatan ekonomi yang ada di suatu wilayah selama kurun waktu setahun. Data laju pertumbuhan PDRB Provinsi Sulawesi Selatan atas dasar harga konstan menurut lapangan usaha selama lima belas tahun dari tahun 2005 hingga tahun 2019 ditunjukkan pada tabel 4 di bawah ini:

Tabel 3. Laju Pertumbuhan Produk Domestik Regional Bruto Atas Dasar Harga Konstan Provinsi Sulawesi Selatan Menurut Lapangan Usaha (persen), Tahun 2005-2019

\begin{tabular}{|c|c|}
\hline Tahun & Laju Pertumbuhan Produk Domestik Regional Bruto \\
\hline 2005 & 6.05 \\
\hline 2006 & 6.72 \\
\hline 2007 & 6.34 \\
\hline 2008 & 7.78 \\
\hline 2009 & 6.20 \\
\hline 2010 & 8.63 \\
\hline 2011 & 8.13 \\
\hline 2012 & 8.87 \\
\hline 2013 & 7.63 \\
\hline 2014 & 7.57 \\
\hline 2015 & 7.19 \\
\hline 2016 & 7.42 \\
\hline
\end{tabular}




\begin{tabular}{|l|l|}
\hline 2017 & 7.21 \\
\hline 2018 & 7.06 \\
\hline 2019 & 6.92 \\
\hline
\end{tabular}

Sumber: Badan Pusat Stastik Sulsel

Berdasarkan tabel diatas pertumbuhan ekonomi Provinsi Sulawesi Selatan selama lima belas tahun (2005-2019) mengalami fluktuatif, pada tahun 2010 laju pertumbuhan ekonomi mengalami peningkatan sebesar 8.63 persen, dan mengalami penurunan pada tahun 2013 sebesar 7.63 persen hingga tahun 2019 laju pertumbuhan ekonomi Provinsi Sulawesi Selatan terus menurun hingga 6.92 persen, menurun dibandingkan tahun sebelumnya.

\section{A. Hasil Penelitian}

1. Analisis Pertumbuhan Ekonomi antar Kabupaten/Kota di Provinsi Sulawesi Selatan

Produk Domestik Regional Bruto (PDRB) merupakan salah satu indikator yang mempengaruhi keberhasilan pembangunan suatu daerah. Peningkatan atau penurunan PDRB menunjukkan bahwa suatu daerah mengalami peningkatan atau penurunan pada sektor pembangunan dan kegiatan ekonomi. Sedangkan pertumbuhan ekonomi merupakan pertumbuhan yang terbagi dalam beberapa sektor ekonomi,dan merupakan sumber penciptaan lapangan kerja. Tinggi rendahnya pertumbuhan ekonomi tercermin dari nilai PDRB setiap tahunnya yang dimana apabila pertumbuhan masingmasing sektor ekonomi meningkat maka akan meningkatkan kontribusinya terhadap besarnya PDRB wilayah tersebut, namun peningkatan PDRB setiap tahunnya tidak sepenuhmya membuat pertumbuhan ekonomi ikut meningkat setiap tahunnya hal ini dapat dilihat pada tabel hasil perhitungan pertumbuhan ekonomi antar Kabupaten/Kota di Provinsi Sulawesi Selatan tahun 20052019 disajikan pada tabel 4 sebagai berikut.

Tabel 4. Pertumbuhan Ekonomi antar Kabupaten/Kota di Provinsi Sulawesi Selatan Atas Dasar Harga Konstan Tahun 2005-2019

\begin{tabular}{|l|c|c|c|c|c|c|c|c|}
\hline \multirow{2}{*}{ Kabupaten/Kota } & \multicolumn{7}{|c|}{ Pertumbuhan Ekonomi antar Kabupaten/Kota (\%) } \\
\cline { 2 - 9 } & $\mathbf{2 0 0 5}$ & $\mathbf{2 0 0 6}$ & $\mathbf{2 0 0 7}$ & $\mathbf{2 0 0 8}$ & $\mathbf{2 0 0 9}$ & $\mathbf{2 0 1 0}$ & $\mathbf{2 0 1 1}$ & $\mathbf{2 0 1 2}$ \\
\hline Kab. Kepulauan Selayar. & $\mathbf{3 , 9 0}$ & 5,57 & 6,45 & 7,27 & 7,89 & 7,96 & 8,88 & 7,88 \\
\hline Kab. Bulukumba. & 4,48 & 6,38 & 5,36 & 8,06 & 6,47 & 5,71 & 5,49 & 9,65 \\
\hline Kab. Bantaeng & 4,35 & 5,10 & 5,37 & 6,73 & 7,32 & 8,32 & 9,38 & 9,67 \\
\hline Kab. Jeneponto. & 1,21 & 3,97 & 4,06 & 5,78 & 5,38 & 6,59 & 8,44 & 7,55 \\
\hline Kab. Takalar. & 5,58 & 5,91 & 6,04 & 6,19 & 6,58 & 8,66 & 7,59 & 6,58 \\
\hline Kab. Gowa. & 5,74 & 6,17 & 6,19 & 6,92 & 7,99 & 6,87 & 7,46 & 8,15 \\
\hline Kab. Sinjai. & 5,23 & 6,11 & 5,43 & 7,45 & 7,02 & 5,89 & 7,60 & 7,32 \\
\hline Kab. Maros. & 3,12 & 4,33 & 4,58 & 5,61 & 6,27 & 12,40 & 11,24 & 11,14 \\
\hline Kab. Pangkep. & 5,61 & 5,92 & 6,12 & 7,16 & 5,91 & 7,96 & 9,84 & 8,26 \\
\hline Kab. Barru. & 4,94 & 4,90 & 4,94 & 6,98 & 5,72 & 6,06 & 8,13 & 8,39 \\
\hline Kab. Bone. & 4,31 & 5,95 & 6,01 & 7,24 & 7,54 & 7,61 & 6,40 & 8,21 \\
\hline Kab. Soppeng. & 2,85 & 6,63 & 5,37 & 7,76 & 6,81 & 6,32 & 7,17 & 6,93 \\
\hline Kab. Wajo. & 5,97 & 5,66 & 5,87 & 7,40 & 5,10 & 5,85 & 10,11 & 6,50 \\
\hline Kab. Sidrap. & 8,25 & 6,96 & 5,46 & 8,23 & 6,66 & 6,24 & 9,63 & 8,93 \\
\hline Kab. Pinrang. & 6,04 & 4,12 & 5,14 & 6,73 & 7,65 & 5,70 & 7,71 & 8,51 \\
\hline Kab. Enrekang. & 5,91 & 3,77 & 5,11 & 6,49 & 6,62 & 5,78 & 8,08 & 7,30 \\
\hline Kab. Luwu. & 7,16 & 5,51 & 5,53 & 5,73 & 6,82 & 7,15 & 7,89 & 7,00 \\
\hline Kab. Tana Toraja. & 3,67 & 5,22 & 5,35 & 7,18 & 6,10 & 7,67 & 7,78 & 8,58 \\
\hline Kab. Luwu Utara. & 8,69 & 7,61 & 6,83 & 9,65 & 6,90 & 6,27 & 8,04 & 6,81 \\
\hline Kab. Luwu Timur. & 5,57 & 6,86 & 5,75 & $-2,44$ & $-4,04$ & 13,19 & $-4,29$ & 5,62 \\
\hline Kota Makassar. & 7,16 & 8,09 & 8,11 & 10,52 & 9,20 & 9,83 & 10,36 & 9,64 \\
\hline Kota Pare-Pare. & 5,98 & 6,96 & 6,98 & 7,56 & 7,93 & 7,99 & 8,42 & 8,80 \\
\hline Kota Palopo & 7,72 & 6,32 & 6,53 & 7,44 & 7,86 & 6,67 & 7,90 & 7,00 \\
\hline Sumber.
\end{tabular}

Sumber: Hasil Olah Data,2021

Lanjutan Tabel 4

\begin{tabular}{|c|c|c|c|c|c|c|c|c|}
\hline \multirow{2}{*}{ Kabupaten/Kota } & \multicolumn{7}{|c|}{ Pertumbuhan Ekonomi antar Kabupaten/Kota (\%) } & Rata-rata \\
\cline { 2 - 9 } & $\mathbf{2 0 1 3}$ & $\mathbf{2 0 1 4}$ & $\mathbf{2 0 1 5}$ & $\mathbf{2 0 1 6}$ & $\mathbf{2 0 1 7}$ & $\mathbf{2 0 1 8}$ & $\mathbf{2 0 1 9}$ & $\begin{array}{c}\mathbf{2 0 0 5 -} \\
\mathbf{2 0 1 9}\end{array}$ \\
\hline Kab.Kepulauan Selayar. & 9,18 & 9,18 & 8,83 & 7,35 & 7,61 & 8,75 & 7,66 & 7,62 \\
\hline
\end{tabular}




\begin{tabular}{|l|c|c|c|c|c|c|c|c|}
\hline Kab. Bulukumba. & 7,79 & 8,21 & 5,62 & 6,77 & 6,89 & 5,05 & 5,49 & 6,52 \\
\hline Kab. Bantaeng & 9,01 & 7,92 & 6,64 & 7,39 & 7,31 & 8,13 & 10,75 & 7,59 \\
\hline Kab. Jeneponto. & 6,65 & 7,71 & 6,54 & 8,32 & 8,26 & 6,29 & 5,47 & 6,16 \\
\hline Kab. Takalar. & 8,80 & 9,00 & 8,42 & 9,61 & 7,38 & 6,66 & 6,87 & 7,37 \\
\hline Kab. Gowa. & 9,44 & 6,94 & 6,79 & 7,57 & 7,21 & 7,14 & 7,46 & 7,22 \\
\hline Kab. Sinjai. & 7,80 & 6,98 & 7,55 & 7,09 & 7,23 & 7,44 & 6,12 & 6,82 \\
\hline Kab. Maros. & 6,28 & 5,23 & 8,44 & 9,50 & 6,81 & 6,19 & 1,24 & 6,80 \\
\hline Kab. Pangkep. & 9,33 & 10,16 & 7,63 & 8,31 & 6,61 & 4,77 & 6,41 & 7,37 \\
\hline Kab. Barru. & 7,91 & 6,64 & 6,32 & 6,01 & 6,48 & 7,11 & 7,41 & 6,57 \\
\hline Kab. Bone. & 6,31 & 8,92 & 8,30 & 9,01 & 8,41 & 8,91 & 7,01 & 7,38 \\
\hline Kab. Soppeng. & 7,24 & 6,76 & 5,11 & 8,11 & 8,29 & 8,11 & 7,69 & 6,75 \\
\hline Kab. Wajo. & 6,86 & 9,15 & 7,06 & 4,96 & 5,21 & 1,08 & 4,06 & 6,09 \\
\hline Kab. Sidrap. & 6,94 & 7,76 & 8,03 & 8,77 & 7,09 & 5,02 & 4,65 & 7,24 \\
\hline Kab. Pinrang. & 7,28 & 8,11 & 8,24 & 7,44 & 7,84 & 6,91 & 6,53 & 6,93 \\
\hline Kab. Enrekang. & 5,84 & 5,88 & 6,91 & 7,63 & 6,84 & 3,26 & 5,43 & 6,06 \\
\hline Kab. Luwu. & 7,74 & 8,73 & 7,26 & 7,88 & 6,79 & 6,86 & 6,26 & 6,96 \\
\hline Kab. Tana Toraja. & 7,28 & 6,56 & 6,85 & 7,29 & 7,47 & 7,89 & 7,22 & 6,82 \\
\hline Kab. Luwu Utara. & 7,40 & 8,47 & 6,67 & 7,49 & 7,60 & 8,39 & 7,11 & 7,62 \\
\hline Kab. Luwu Timur. & 6,31 & 8,47 & 6,42 & 1,58 & 3,07 & 3,39 & 1,17 & 3,78 \\
\hline Kota Makassar. & 8,55 & 7,39 & 7,55 & 8,03 & 8,20 & 8,42 & 8,79 & 8,65 \\
\hline Kota Pare-Pare. & 7,97 & 6,09 & 6,30 & 6,87 & 6,98 & 5,58 & 6,65 & 7,15 \\
\hline Kota Palopo & 8,08 & 6,66 & 6,47 & 6,95 & 7,17 & 7,52 & 6,75 & 7,16 \\
\hline Sumber. & & & & &
\end{tabular}

Sumber: Hasil Olah Data,2021

Berdasarkan hasil perhitungan pada Tabel 4 dapat dilihat bahwa pertumbuhan ekonomi antar Kabupaten/Kota mengalami fluktuasi. Dapat dilihat pertumbuhan ekonomi tertinggi dengan ratarata 8,65 yaitu terdapat di kota Makassar yang menjadi pusat ibu kota daerah Sulawesi Selatan dan menjadi pusat baik itu bidang sosial maupun ekonomi. Sedangkan pertumbuhan ekonomi terendah terdapat di Kabupaten Luwu Timur dengan rata-rata 3,78, hal tersebut terjadi karena mengalami penurunan di sektor pertambangan, sektor pertanian, dan sektor perkebunan. Ekonomi di bidang pertambangan mengalami penurunan karena saat ini kabupaten Luwu Timur hanya mengandalkan PT Vale, adapun PT CLM dan PT PUL yang juga bergerak di bidang pertambangan saat ini belum terlalu signifikan berpoduksi, sedangkan penurunan ekonomi di sektor pertanian dan perkebunan disebabkan cuaca ekstrim serta cuaca yang tidak menentu, sehingga hal tersebut dapat mempengaruhi pertumbuhan ekonomi kabupaten Luwu Timur. Berfluktuatifnya pertumbuhan ekonomi disebabkan oleh naik turunya nilai berbagai sektor ekonomi yang menjadi sektor unggulan seperti pertambangan dan sektor pertanian.

\section{Analisis Tipologi Klassen.}

Metode Tipologi Klassen digunakan untuk mengetahui pengelompokkan sektor ekonomi yang ada di Provinsi Sulawesi Selatan menurut struktur pertumbuhannya. Dengan menggunakan Matrix Klassen dapat dilakukan empat pengelompokkan sektor dengan memanfaatkan laju pertumbuhan dan nilai kontribusi. Laju Pertumbuhan dan Kontribusi Sektor PDB Provinsi Sulawesi Selatan dan PDRB Kabupaten/Kota tahun 2005-2019 dapat dilihat pada tabel berikut.

Tabel 5. Klasifikasi Kabupaten/Kota di Provinsi Sulawesi Selatan Tahun 2005-2019 Menurut Kriteria Tipologi Daerah Berdasakan Tipologi Klassen

\begin{tabular}{|c|c|}
\hline $\begin{array}{c}\text { Kuadran I } \\
\text { (Daerah Maju dan Tumbuh Cepat) } \\
\text { Kota Makassar, Kabupaten Pangkep. }\end{array}$ & $\begin{array}{c}\text { Kuadran II } \\
\text { (Daerah Maju Tapi Tertekan) } \\
\text { Kabupaten Luwu Timur. }\end{array}$ \\
\hline $\begin{array}{c}\text { Kuadran III } \\
\text { (Daerah Berkembang Cepat) }\end{array}$ & $\begin{array}{c}\text { Kuadran IV } \\
\text { (Daerah Relatif Tertinggal) }\end{array}$ \\
Kabupaten Kepulauan Selayar, Kabupaten Bantaeng, & Kabupaten Bulukumba, Kabupaten Jeneponto, \\
Kabupaten Takalar, Kabupaten Bone, Kabupaten Luwu & Kabupaten Gowa, Kabupaten Sinjai, Kabupaten \\
Utara. & Maros, Kabupaten Barru, Kabupaten Soppeng, \\
& Kabupaten Wajo, Kabupaten Sidrap, Kabupaten \\
& Pinrang, Kabupaten Enrekang, Kabupaten Luwu, \\
& Kabupaten Tana Toraja, Kota Pare-pare, Kota Palopo. \\
\hline
\end{tabular}


Berdasarkan hasil Klasifikasi Tipologi Daerah Provinsi Sulawesi Selatan Tahun 2005-2019 Berdasarkan Tipologi Klassen, maka terdapat daerah yang dapat dikategorikan sebagai Daerah Maju dan Tumbuh Cepat atau kuadran I yaitu (1) Kabupaten Pangkep, (2) Kota Makassar. Untuk Daerah Maju Tapi Tertekan atau kuadran II yaitu (1) Kabupaten Luwu Timur. Daerah yang masuk kuadran III sebagai Daerah Berkembang Cepat yaitu (1) Kabupaten Kepulauan Selayar, (2) Kabupaten Bantaeng, (3) Kabupaten Takalar, (4) Kabupaten Bone, (5) Kabupaten Luwu Utara. Sedangkan yang masuk kuadran IV sebagai Daerah Relatif Tertinggal yaitu (1) Kabupaten Bulukumba, (2) Kabupaten Jeneponto, (3) Kabupaten Gowa, (4) Kabupaten Sinjai, (5) Kabupaten Maros, (6) Kabupaten Barru, (7) Kabupaten Soppeng, (8) Kabupaten Wajo, (9) Kabupaten Sidrap, (10) Kabupaten Pinrang, (11) Kabupaten Enrekang, (12) Kabupaten Luwu, (13) Kabupaten Tana Toraja, (14) Kota Pare-pare, (15) Kota Palopo.

\section{Analisis Disparitas Pendapatan Antar Kabupaten/Kota Menggunkan Alat Analisis Indeks Williamson.}

Ada banyak cara dalam mengukur pembangunan wilayah atau daerah di suatu area, seperti Produk Domestik Bruto, koefisien GINI, shift-share, Human Development Index, dan masih banyak lagi. Masing-masing instrumen tersebut memainkan peran yang berbeda dalam mengukur pembangunan itu sendiri, yang digunakan dalam penelitian ini adalah Indeks Williamson. Indeks Williamson merupakan satu instrumen dalam pengukuran ketimpangan pendapatan untuk menganalisis seberapa besar kesenjangan antar Kabupaten/kota.

Hasil perhitungan tingkat kesenjangan antar Kabupaten/Kota di Provinsi Sulawesi Selatan dengan menggunakan Indeks Williamson dapat dilihat pada Tabel berikut :

Tabel 6. Indeks Williamson Kabupaten/Kota Provinsi Sulawesi Selatan Tahun 2005-2019

\begin{tabular}{|l|c|c|c|c|c|c|c|c|}
\hline \multirow{2}{*}{ Kabupaten/Kota } & \multicolumn{9}{|c|}{ Indeks Williamson } \\
\cline { 2 - 9 } & $\mathbf{2 0 0 5}$ & $\mathbf{2 0 0 6}$ & $\mathbf{2 0 0 7}$ & $\mathbf{2 0 0 8}$ & $\mathbf{2 0 0 9}$ & $\mathbf{2 0 1 0}$ & $\mathbf{2 0 1 1}$ & $\mathbf{2 0 1 2}$ \\
\hline Kab. Kepulauan Selayar. & 0,05 & 0,05 & 0,05 & 0,05 & 0,05 & 0,10 & 0,04 & 0,04 \\
\hline Kab. Bulukumba. & 0,06 & 0,06 & 0,06 & 0,07 & 0,07 & 0,18 & 0,10 & 0,10 \\
\hline Kab. Bantaeng & 0,05 & 0,05 & 0,05 & 0,05 & 0,05 & 0,12 & 0,04 & 0,04 \\
\hline Kab. Jeneponto. & 0,11 & 0,11 & 0,12 & 0,12 & 0,12 & 0,18 & 0,11 & 0,11 \\
\hline Kab. Takalar. & 0,08 & 0,08 & 0,08 & 0,08 & 0,08 & 0,15 & 0,08 & 0,08 \\
\hline Kab. Gowa. & 0,14 & 0,14 & 0,14 & 0,15 & 0,14 & 0,25 & 0,14 & 0,14 \\
\hline Kab. Sinjai. & 0,04 & 0,04 & 0,04 & 0,04 & 0,04 & 0,13 & 0,04 & 0,04 \\
\hline Kab. Maros. & 0,07 & 0,07 & 0,08 & 0,08 & 0,08 & 0,17 & 0,02 & 0,03 \\
\hline Kab. Pangkep. & 0,09 & 0,06 & 0,07 & 0,06 & 0,06 & 0,12 & 0,07 & 0,07 \\
\hline Kab. Barru. & 0,04 & 0,04 & 0,04 & 0,04 & 0,04 & 0,11 & 0,04 & 0,04 \\
\hline Kab. Bone. & 0,09 & 0,09 & 0,09 & 0,09 & 0,09 & 0,24 & 0,09 & 0,09 \\
\hline Kab. Soppeng. & 0,03 & 0,03 & 0,03 & 0,03 & 0,03 & 0,12 & 0,04 & 0,04 \\
\hline Kab. Wajo. & 0,01 & 0,01 & 0,01 & 0,00 & 0,00 & 0,15 & 0,02 & 0,02 \\
\hline Kab. Sidrap. & 0,01 & 0,00 & 0,00 & 0,01 & 0,01 & 0,14 & 0,04 & 0,04 \\
\hline Kab. Pinrang. & 0,04 & 0,04 & 0,03 & 0,03 & 0,03 & 0,14 & 0,03 & 0,03 \\
\hline Kab. Enrekang. & 0,05 & 0,05 & 0,05 & 0,06 & 0,06 & 0,13 & 0,06 & 0,06 \\
\hline Kab. Luwu. & 0,03 & 0,03 & 0,03 & 0,04 & 0,04 & 0,16 & 0,06 & 0,06 \\
\hline Kab. Tana Toraja. & 0,18 & 0,18 & 0,18 & 0,11 & 0,10 & 0,14 & 0,08 & 0,08 \\
\hline Kab. Luwu Utara. & 0,04 & 0,04 & 0,04 & 0,05 & 0,05 & 0,14 & 0,06 & 0,06 \\
\hline Kab. Luwu Timur. & 0,50 & 0,49 & 0,49 & 0,41 & 0,35 & 0,01 & 0,18 & 0,16 \\
\hline Kota Makassar. & 0,34 & 0,34 & 0,36 & 0,36 & 0,38 & 0,18 & 0,44 & 0,45 \\
\hline Kota Pare-Pare. & 0,04 & 0,00 & 0,00 & 0,02 & 0,04 & 0,09 & 0,00 & 0,00 \\
\hline Kota Palopo & 0,01 & 0,01 & 0,00 & 0,00 & 0,00 & 0,10 & 0,01 & 0,01 \\
\hline
\end{tabular}

Sumber: Hasil Olah Data, 2021.

Lanjutan Tabel 6.

\begin{tabular}{|l|c|c|c|c|c|c|c|c|}
\hline \multirow{2}{*}{ Kabupaten/Kota } & \multicolumn{7}{|c|}{ Indeks Williamson } & Kriteria \\
\cline { 2 - 9 } & $\mathbf{2 0 1 3}$ & $\mathbf{2 0 1 4}$ & $\mathbf{2 0 1 5}$ & $\mathbf{2 0 1 6}$ & $\mathbf{2 0 1 7}$ & $\mathbf{2 0 1 8}$ & $\mathbf{2 0 1 9}$ & $\mathbf{2 0 0 5 - 2 0 1 9}$ \\
\hline Kab. Kepulauan Selayar. & 0,04 & 0,04 & 0,04 & 0,04 & 0,04 & 0,03 & 0,03 & Rendah \\
\hline Kab. Bulukumba. & 0,10 & 0,10 & 0,10 & 0,10 & 0,10 & 0,10 & 0,10 & Rendah \\
\hline
\end{tabular}




\begin{tabular}{|l|l|l|l|l|l|l|l|l|}
\hline Kab. Bantaeng & 0,04 & 0,04 & 0,11 & 0,04 & 0,03 & 0,03 & 0,03 & Rendah \\
\hline Kab. Jeneponto. & 0,09 & 0,11 & 0,11 & 0,10 & 0,10 & 0,10 & 0,10 & Rendah \\
\hline Kab. Takalar. & 0,08 & 0,08 & 0,08 & 0,07 & 0,07 & 0,07 & 0,07 & Rendah \\
\hline Kab. Gowa. & 0,14 & 0,15 & 0,15 & 0,15 & 0,15 & 0,15 & 0,15 & Rendah \\
\hline Kab. Sinjai. & 0,04 & 0,04 & 0,04 & 0,04 & 0,04 & 0,04 & 0,04 & Rendah \\
\hline Kab. Maros. & 0,02 & 0,02 & 0,11 & 0,02 & 0,02 & 0,02 & 0,01 & Rendah \\
\hline Kab. Pangkep. & 0,07 & 0,08 & 0,08 & 0,08 & 0,08 & 0,07 & 0,07 & Rendah \\
\hline Kab. Barru. & 0,04 & 0,04 & 0,12 & 0,04 & 0,04 & 0,04 & 0,04 & Rendah \\
\hline Kab. Bone. & 0,08 & 0,08 & 0,25 & 0,07 & 0,07 & 0,07 & 0,06 & Rendah \\
\hline Kab. Soppeng. & 0,04 & 0,04 & 0,04 & 0,04 & 0,03 & 0,03 & 0,03 & Rendah \\
\hline Kab. Wajo. & 0,04 & 0,01 & 0,03 & 0,01 & 0,01 & 0,02 & 0,03 & Rendah \\
\hline Kab. Sidrap. & 0,04 & 0,04 & 0,04 & 0,04 & 0,04 & 0,04 & 0,05 & Rendah \\
\hline Kab. Pinrang. & 0,02 & 0,02 & 0,02 & 0,02 & 0,02 & 0,02 & 0,02 & Rendah \\
\hline Kab. Enrekang. & 0,06 & 0,06 & 0,06 & 0,06 & 0,06 & 0,06 & 0,06 & Rendah \\
\hline Kab. Luwu. & 0,06 & 0,06 & 0,06 & 0,06 & 0,06 & 0,06 & 0,06 & Rendah \\
\hline Kab. Tana Toraja. & 0,08 & 0,08 & 0,08 & 0,08 & 0,08 & 0,08 & 0,08 & Rendah \\
\hline Kab. Luwu Utara. & 0,06 & 0,06 & 0,06 & 0,06 & 0,06 & 0,06 & 0,06 & Rendah \\
\hline Kab. Luwu Timur. & 0,16 & 0,15 & 0,15 & 0,12 & 0,11 & 0,10 & 0,08 & Rendah \\
\hline Kota Makassar. & 0,46 & 0,45 & 0,45 & 0,45 & 0,45 & 0,46 & 0,48 & Sedang \\
\hline Kota Pare-Pare. & 0,00 & 0,01 & 0,01 & 0,01 & 0,01 & 0,01 & 0,01 & Rendah \\
\hline Kota Palopo & 0,02 & 0,02 & 0,02 & 0,03 & 0,03 & 0,03 & 0,03 & Rendah \\
\hline
\end{tabular}

Sumber: Hasil Olah Data,2021

Hasil perhitungan dengan menggunakan Indeks Williamson menunjukkan terjadinya disparitas atau kesenjangan pendapatan antar kabupaten/kota di Provinsi Sulawesi Selatan Tahun 2005-2019 yang ditunjukkan oleh nilai indeks Williamson yang lebih besar dari 0, kesenjangan yang paling rendah terdapat pada Kabupaten Wajo, Kota Pare-Pare dan Kota Palopo dengan rata-rata nilai indeks williamson tahun 2005-2019 sebesar 0,02. Dapat di lihat pada tabel di atas bahwa ketimpangan yang tinggi yaitu terdapat pada Kota Makassar dengan rata-rata 0,40, termasuk dalam kriteria sedang. Secara rata-rata kesenjangan antar kabupaten/kota di Provinsi Sulawesi Selatan selama tahun 20052019 tergolong dalam kategori rendah, ini ditunjukkan dengan nilai rata-rata sebesar 0,09.

\section{Analisis Hubungan Pertumbuhan Ekonomi dan Disparitas Pendapatan Terhadap Kesejahteraan Antar Daerah Kabupaten/kota di Provinsi Sulawesi Selatan Menggunakan Regresi Data Panel.}

Regresi data panel digunakan untuk menganalisis hubungan pertumbuhan ekonomi dan disparitas pendapatan terhadap kesejahteraan masyarakat di Provinsi Sulawesi Selatan. Data yang digunakan dalam penelitian ini adalah data cross section dan time series, dimana data ini menggambarkan beberapa objek penelitian dalam kurun waktu yang berbeda-beda dan diolah menggunakan program E-views 10. Objek dalam penelitian ini adalah 23 kabupaten/kota di Provinsi Sulawesi Selatan tahun 2005-2019. Ada tiga model yang dapat dipilih dalam regresi data panel dan dipilih model manakah yang paling tepat. Model yang tepat digunakan untuk mengestimasi parameter regresi data panel dalam menganalisis hubungan pertumbuhan ekonomi dan disparitas pendaptan terhadap kesejahteraan masyarakat di Provinsi Sulawesi Selatan tahun 2005-2019.

\section{1) Pemilihan Model Estimasi Regresi Data Panel}

a. Uji Chow (Likelihood Test Ratio)

Uji Chow (Likelihood Ratio) digunakan untuk memilih model regresi data panel yang paling baik antara Pooled Least Square dan Fixed Effect Model. Aplikasi yang digunakan untuk uji Chow menggunakan program E-views 10. Hasil pengolahan ditunjukan pada tabel berikut :

Tabel 7. Hasil Uji Chow (Likelihood Test Ratio)

\begin{tabular}{|l|r|r|r|}
\hline Effects Test & Statistic & d.f. & Prob. \\
\hline Cross-section F & 55.834637 & $(22,320)$ & 0.0000 \\
\hline Cross-section Chi-square & 543.938004 & 22 & 0.0000 \\
\hline
\end{tabular}


Output regresi Chow test menunjukkan nilai probabilitas F-statistik $=0,0000 \leq 0,05$, maka H0 ditolak dan H1 diterima sehingga model yang terpilih yaitu fixed effect Model (FEM).

\section{b. Uji Hausman}

Uji Hausman digunakan untuk memilih model regresi data panel yang paling baik antara Fixed Effect Model dan Random Effect Model. Aplikasi yang digunakan untuk uji Hausman menggunakan program Eviews 10. Hasil pengolahan ditunjukan pada tabel berikut :

Tabel 8. Hasil Uji Hausman Test

\begin{tabular}{|l|r|r|r|}
\hline Test Summary & Chi-Sq. Statistic & Chi-Sq. d.f. & Prob. \\
\hline Cross-section random & 8.590663 & 2 & 0.0136 \\
\hline
\end{tabular}

Sumber: Hasil Olah Data,2021

Output regresi Hausman test menunjukkan nilai probabilitas Chi-square statistic $=0.0136 \leq 0,05$, maka H0 ditolak dan H1 diterima, sehingga model yang terpilih yaitu fixed effect Model (FEM). Berdasarkan hasil estimasi data panel untuk memilih model yang terbaik antara Uji Chow, Uji Hausman dan Uji Lagrange Multiplier, maka terpilih fixed effect Model sebagai model yang paling tepat untuk menganalisis data dalam penelitian ini. Karena model yang tepat untuk digunakan dalam menganalisis data dalam penelitian ini sudah di dapat, yang dimana pada Uji Chow dan Uji Hausman sama-sama terpilh fixed effect Model sehingga tidak perlu lagi melakukan Uji Lagrange Multiplier. Berdasarkan model hasil estimasi pada pembahasan sebelumnya tersebut diperoleh nilai konstanta dan koefisien dari masing-masing variabel yaitu sebagai berikut :

Tabel 9. Model regresi data panel fixed effect Model (FEM).

\begin{tabular}{|l|r|r|r|r|}
\hline \multicolumn{1}{|c|}{ Variable } & Coefficient & Std. Error & t-Statistic & Prob. \\
\hline C & 71.99869 & 0.510146 & 141.1336 & 0.0000 \\
\hline Pertumbuhan Ekonomi & -0.415164 & 0.063451 & -6.543032 & 0.0000 \\
\hline Disparitas & -8.962693 & 2.330170 & -3.846369 & 0.0001 \\
\hline R-squared & 0.806545 & Mean dependent var & 68.37241 \\
\hline F-statistic & 55.58884 & Durbin-Watson stat & 0.749701 \\
\hline Prob(F-statistic) & 0.000000 & & \\
\hline
\end{tabular}

Sumber: Hasil Olah Data,2021

Dari hasil estimasi di atas, maka dapat dibentuk persamaan regresi data panel sebagai berikut :

$\mathrm{KSJRM}_{\mathrm{it}}=71.99869-0.415164 \mathrm{PE}_{\mathrm{it}}-8.962693 \mathrm{DP} \mathrm{it}_{\mathrm{it}}+\varepsilon_{\mathrm{it}}$

Persamaan model regresi tersebut dapat dijelaskan secara terperinci sebagai berikut :

1. $\beta_{0}=71.99869$ merupakan nilai konstanta. Nilai tersebut menunjukkan bahwa tingkat kesejahteraan masyarakat sebesar 71.99869 persen apabila variabel pertumbuhan ekonomi dan disparitas pendapatan konstan.

2. $\beta_{1}=-0.415164$ merupakan koefisien regresi variabel pertumbuhan ekonomi. Nilai tersebut menunjukkan hubungan pertumbuhan ekonomi terhadap kesejahteraan masyarakat sebesar 0.415164 artinya, apabila terjadi kenaikan pertumbuhan ekonomi sebesar satu persen maka akan menurunkan tingkat kesejahteraan masyarakat yang diukur dengan indikator IPM sebesar 0.415164 persen dengan asumsi variabel lain konstan.

3. $\beta_{2}=-8.962693$ merupakan koefisien regresi variabel disparitas pendapatan. Nilai tersebut menunjukkan hubungan disparitas pendapatan terhadap kesejahteraan masyarakat sebesar 8.962693 artinya, apabila terjadi kenaikan disparitas pendapatan sebesar satu persen maka akan menurunkan tingkat kesejahteraan masyarakat yang diukur dengan indikator IPM sebesar 8.962693 persen dengan asumsi variabel lain konstan.

Dari hasil estimasi model diketahui probabilitas untuk variabel Pertumbuhan Ekonomi memiliki probabilitas 0.0000 lebih kecil dari 0,05 yang berarti bahwa variabel pertumbuhan ekonomi berhubungan signifikan terhadap kesejahteraan masyarakat. Sedangkan untuk variabel Disparitas Pendapatan berhubungan signifikan terhadap Kesejahteraan masyarakat dengan nilai probabilitas yaitu 0.0001 yang dimana lebih kecil dari 0,05. 


\section{2) Uji Statistik}

Dari persamaan regresi data panel, selanjutnya diadakan pengujian statistik, diantaranya ialah: a) Uji t (uji hubungan secara parsial), b) Uji F (uji hubungan secara simultan), c) Uji R2 (koefisien determinasi).

\section{a. Uji t (Uji Hubungan Secara Parsial)}

Uji statistik $t$ pada dasarnya menunjukkan seberapa jauh hubungan masing-masing variabel independen secara individual dalam menerangkan variasi variabel dependen.

Tabel 10. Nilai (Uji t) Hubungan Pertumbuhan Ekonomi dan Disparitas Pendapatan Terhadap Kesejahteraan Masyarakat

\begin{tabular}{|c|c|c|c|c|c|}
\hline Variabel & t-Statistik & t-Tabel df & Probabilitas & $\alpha=5 \%$ & Keterangan \\
\hline Pertumbuhan Ekonomi & -6.543032 & 1,64931 & 0.0000 & 0,05 & Signifikan \\
\hline Disparitas & -3.846369 & 1,64931 & 0.0001 & 0,05 & Signifikan \\
\hline
\end{tabular}

Sumber: Hasil Olah Data,2021

Dari hasil estimasi di atas menunjukkan bahwa secara parsial variabel bebas (pertumbuhan ekonomi dan disparitas) mempunyai hubungan signifikan terhadap variabel terikat (kesejateraan masyarakat) dengan nilai yang negatif.

a) Pertumbuhan Ekonomi

Variabel pertumbuhan ekonomi mempunyai nilai t-statistik $-6.543032<\mathrm{t}$-tabel 1,96690 dan nilai probabilitas t-statistik $0.0000 \leq 0,05$ maka $\mathrm{H} 0$ ditolak dan $\mathrm{H} 1$ diterima, artinya secara parsial pertumbuhan ekonomi berhubungan negatif dan signifikan terhadap kesejahteraan masyarakat Kabupaten/kota di Provinsi Sulawesi Selatan, sehingga hipotesis diterima.

b) Disparitas Pendapatan

Variabel disparitas pendapatan mempunyai nilai t-statistik $-3.846369<$ t-tabel 1,64931 dan nilai probabilitas t-statistik $0.0001 \leq 0,05$ maka H0 ditolak dan H1 diterima, artinya secara parsial disparitas pendapatan berhubungan negatif dan signifikan terhadap kesejahteraan masyarakat antar daerah Kabupaten/kota di Provinsi Sulawesi Selatan, sehingga hipotesis diterima.

\section{b. Uji F (Uji Hubungan Secara Simultan)}

Pengujian terhadap hubungan semua variabel independen di dalam model dapat dilakukan dengan uji simultan (uji F). Uji statistik F pada dasarnya menunjukkan apakah semua variabel independen yang dimasukkan dalam model mempunyai hubungan secara bersama-sama terhadap variabel dependen. Dari hasil estimasi dengan mengambil a sebesar 5\% maka dari tabel distribusi $\mathrm{F}$ diperoleh nilai F-tabel untuk $\mathrm{F}_{0,05}$ adalah 3,02. Berdasarkan hasil perhitungan melalui program Eviews 10 diperoleh nilai F-statistik sebesar 55.58884 sehingga dapat dibandingkan bahwa F-statistik > F-tabel. Ini diperkuat dengan nilai probabilitas F-statistik $=0,000000 \leq$ nilai probabilitas $\alpha=0,05$ maka H0 ditolak dan H1 diterima, artinya berpengaruh signifikan dan simultan, semua variabel independen mampu menjelaskan variabel dependen atau secara bersama-sama.

\section{c. Uji R $\mathbf{R}^{2}$ (Koefisien Determinasi)}

Koefisien determinasi $\left(R^{2}\right)$ pada intinya mengukur seberapa jauh kemampuan model dalam menerangkan variasi variabel dependen. Nilai koefisien determinasi adalah berkisar antara nol sampai satu $\left(0<R^{2}<1\right)$. Nilai $R^{2}$ yang kecil berarti kemampuan variabel-variabel independen dalam menjelaskan variasi-variabel dependen amat terbatas. Nilai yang mendekati satu berarti variabelvariabel independen memberikan hampir semua informasi yang dibutuhkan untuk memprediksi variasi variabel dependen. Hasil perhitungan dengan program E-views 10 menunjukkan nilai Rsquared $=0.806545$, artinya variabel dependen (kesejateraan masyarakat) antar kabupaten $/$ kota di Provinsi Sulawesi Selatan mampu dijelaskan oleh variabel-variabel independen (pertumbuhan ekonomi dan disparitas pendapatan) sebesar 80,65\%, sedangkan sisanya 19,35\% dijelaskan oleh variabel-variabel lain diluar model.

\section{B. Pembahasan Penelitian}

1. Pertumbuhan Ekonomi antar Kabupaten/kota di Provinsi Sulawesi Selatan 
Hasil olah data yang ada pada tabel 5 dilihat bahwa pertumbuhan ekonomi antar kabupaten/kota di Provinsi Sulawesi Selatan berfluktuasi. Dimana pertumbuhan ekonomi tertinggi dengan rata-rata 8,65 terdapat di Kota Makassar dan pertumbuhan ekonomi terendah yaitu di Kabupaten Luwu Timur dengan rata-rata 3,78. Tinggi rendahnya tingkat pertumbuhan ekonomi antar Kabupaten/kota di Provinsi Sulawesi Selatan di pengaruhi oleh faktor ekonomi dan faktor non ekonomi. Faktor ekonomi yang meliputi ; sumber daya alam, modal, kemajuan teknologi, pembagian kerja dan skala produksi, sedangkan faktor non ekonomi meliputi ; faktor sosial, faktor manusia, faktor politik dan administrasi kerja (Mukhtar, 2015:48). Penyebab pertumbuhan ekonomi di Kota Makassar jauh lebih tinggi dibandingkan dengan daerah-daerah lainnya, dikarenakan Kota Makassar adalah pusat Ibu Kota Provinsi Sulawesi Selatan yang menjadi pusat perdagangan, perindustrian, dan sektor jasa.

Dengan demikian laju pertumbuhan ekonomi Kota Makassar akan meningkat dengan cepat dibandingkan dengan daerah-daerah lain yang di dominasi oleh sektor pertanian. Pertumbuhan ekonomi terendah yaitu Kabupaten Luwu Timur dengan rata-rata 3,78, hal ini dikarenakan Kabupaten Luwu Timur hanya mengandalkan sektor pertambangan, sektor pertanian dan sektro perkebunan sebagai penunjang laju pertumbuhan ekonominya, sehingga ketika sektor ini mengalami kendala ataupun penurunan maka akan mempengaruhi pertumbuhan ekonomi Kabupaten Luwu Timur. Berfluktuatifnya pertumbuhan ekonomi disebabkan oleh naik turunnya nilai sektor unggulan di tiap daerah Kabupaten/kota di Provinsi Sulawesi Selatan sehingga akan mempengaruhi tingkat laju pertumbuhan ekonomi suatu daerah, apalagi daerah Kabupaten/kota di Provinsi Sulawesi Selatan masih di dominasi oleh sektor pertanian yang mimiliki ketergantungan pada keadaan alam atau cuaca.

\section{Analisis Tipologi Klassen}

Hasil penelitian dengan menggunakan analisis Klasifikasi Tipologi Daerah berdasarkan Tipologi Klassen yang membagi daerah menjadi empat kuadran adalah daerah cepat maju dan cepat tumbuh, daerah maju tapi tertekan, daerah berkembang pesat dan daerah relative tertinggal. Penerapan klasifikasi daerah Kabupaten/kota di Provinsi Sulawesi Selatan terdiri atas 23 Kabupaten/kota, hasil perhitungan tipologi klassen antar daerah Kabupaten/kota di Provinsi Sulawesi Selatan pada tahun 2005-2019, menyatakan bahwa Kabupaten/kota yang tergolong :

\section{a. Daerah maju dan tumbuh cepat (Kuadran I)}

Daerah maju dan tumbuh cepat (Kuadran I) adalah Kota Makassar dan Kabupaten Pangkep, hal ini dikarenakan nilai rata-rata PDRB Perkaipta dan rata-rata laju pertumbuhan ekonomi Kota Makassar dan Kabupaten Pangkep di atas rata-rata PDRB Perkapita dan rata-rata laju pertumbuhan ekonomi Provinsi Sulawesi Selatan, dapat lihat pada tabel berikut ini :

Tabel 11. Hasil Analisis Tipologi Klassen Tahun 2005-2019

\begin{tabular}{|l|c|c|c|c|}
\hline Kabupaten/kota & $\begin{array}{c}\text { Rata-rata PDRB } \\
\text { Perkapita }\end{array}$ & $\begin{array}{c}\text { Rata-rata laju } \\
\text { pertumbuhan } \\
\text { ekonomi }\end{array}$ & $\begin{array}{c}\text { Rata-rata PDRB } \\
\text { Perkapita }\end{array}$ & $\begin{array}{c}\text { Rata-rata laju } \\
\text { pertumbuhan } \\
\text { ekonomi }\end{array}$ \\
\cline { 2 - 5 } & Kabupaten/kota & Kabupaten/kota & $\begin{array}{c}\text { Provinsi Sulawesi } \\
\text { Selatan }\end{array}$ & $\begin{array}{c}\text { Provinsi } \\
\text { Sulawesi Selatan }\end{array}$ \\
\hline Kota Makassar & 41,70 & 8,65 & 21,04 & 7,31 \\
\hline Kabupaten Pangkep & 27,36 & 7,37 & & \\
\hline
\end{tabular}

Sumber : Hasil Olah Data 2021

Kota Makassar berperan sebagai pusat perdagangan dan jasa, pusat kegiatan industri, pusat kegiatan pemerintahan, dan pusat pelayanan pendidikan dan kesehatan. Selain itu secara geografis Kota Makassar sangat strategis dilihat dari sisi kepentingan ekonomi maupun politik. Dari sisi ekonomi, Kota Makassar menjadi simpul jasa distribusi yang tentunya akan lebih efisien dibandingkan dengan daerah lain. Sedangkan Kabupaten Pangkep memiliki sektor unggulan dibidang perdagangan, industri pengolahan, serta memiliki potensi budidaya tambak yang cukup luas yaitu luasnya mencapai 12.527 ha (luas kotor) dengan produksi yang terdiri dari udang windu, udang api-api, mujair, rumput laut dan ikan lainnya. Hal inilah yang mendorong tingginya PDRB Perkapita dan laju pertumbuhan ekonomi Kota Makassar dan Kabupaten Pangkep dengan cepat 
dibandingkan dengan Provinsi Sulawesi Selatan sehingga masuk dalam kategori daerah maju dan tumbuh cepat (Kuadran I).

\section{b. Daerah maju tapi tertekan (Kuadran II)}

Yang termasuk dalam kriteria daerah maju tapi tertekan (Kuadran II) yaitu Kabupaten Luwu Timur. Kabupaten Luwu Timur memiliki rata-rata PDRB Perkaipta di atas rata-rata PDRB Perkapita Provinsi Sulawesi Selatan dan rata-rata laju pertumbuhan ekonomi di bawah rata-rata laju pertumbuhan ekonomi Provinsi Sulawesi Selatan, dapat lihat pada tabel berikut ini :

Tabel 12. Hasil Analisis Tipologi Klassen Tahun 2005-2019

\begin{tabular}{|c|c|c|c|c|}
\hline \multirow{2}{*}{ Kabupaten/kota } & $\begin{array}{c}\text { Rata-rata PDRB } \\
\text { Perkapita }\end{array}$ & $\begin{array}{c}\text { Rata-rata laju } \\
\text { pertumbuhan } \\
\text { ekonomi }\end{array}$ & $\begin{array}{c}\text { Rata-rata } \\
\text { PDRB } \\
\text { Perkapita }\end{array}$ & $\begin{array}{c}\text { Rata-rata laju } \\
\text { pertumbuhan ekonomi }\end{array}$ \\
\cline { 2 - 5 } & Kabupaten/kota & Kabupaten/kota & $\begin{array}{c}\text { Provinsi } \\
\text { Sulawesi } \\
\text { Selatan }\end{array}$ & $\begin{array}{c}\text { Provinsi Sulawesi } \\
\text { Selatan }\end{array}$ \\
\hline Kabupaten Luwu Timur & 38,39 & 3,78 & 21,04 & 7,31 \\
\hline
\end{tabular}

Sumber : Hasil Olah Data 2021

Kabupaten Luwu Timur memiliki sektor unggulan yaitu sektor pertanian, perikanan, sektor industri pengolahan dan perdagangan, serta sektor pertambangan. Selama ini yang menjadi daya tarik Kabupaten Luwu Timur bagi para investor merupakan sumber daya alam, mulai dari sektor pertambangan yaitu Nikel dan besi, serta di sektor pertanian dalam arti yang luas seperti tanaman pangan, perkebunan, dan perikanan. Selain itu, Kabupaten Luwu Timur saat ini memiliki nilai ekspor yang tinggi untuk Provinsi Sulawesi Selatan dengan menyumbang 45\% dari total nilai ekspor tertinggi Sulawesi Selatan. Dalam upaya yang dilakukan oleh pemerintah Kabupaten Luwu Timur untuk menarik investor, pemerintah membuat kabijakan yang memudahkan para investor, serta memungkinkan para investor untuk dapat menanamkan modalnya di Kabupaten Luwu Timur dengan memenuhi persyaratannya tanpa harus berkunjung langsung. Sehingga hal inilah yang mendorong tingginya rata-rata PDRB Perkapita di Kabupaten Luwu Timur dibandingkan rata-rata PDRB Perkapita Provinsi Sulawesi Selatan.

\section{c. Daerah berkembang cepat (Kuadran III)}

Yang termasuk dalam kategori daerah berkembang cepat (Kuadran III) adalah Kabupaten Kepulauan Selayar, Kabupaten Bantaeng, Kabupaten Takalar, Kabupaten Bone, dan Kabupaten Luwu Utara. Hal ini dikarenakan rata-rata PDRB Perkapita Kabupaten di bawah rata-rata PDRB Perkapita Provinsi Sulawesi Selatan, di atas rata-rata laju pertumbuhan ekonomi Provinsi Sulawesi Selatan, dapat lihat pada tabel berikut ini :

Tabel 13. Hasil Analisis Tipologi Klassen Tahun 2005-2019

\begin{tabular}{|l|c|c|c|c|}
\hline \multicolumn{1}{|c|}{ Kabupaten/kota } & $\begin{array}{c}\text { Rata-rata PDRB } \\
\text { Perkapita }\end{array}$ & $\begin{array}{c}\text { Rata-rata laju } \\
\text { pertumbuhan } \\
\text { ekonomi }\end{array}$ & $\begin{array}{c}\text { Rata-rata PDRB } \\
\text { Perkapita }\end{array}$ & $\begin{array}{c}\text { Rata-rata laju } \\
\text { pertumbuhan } \\
\text { ekonomi }\end{array}$ \\
\cline { 2 - 3 } & Kabupaten/kota & Kabupaten/kota & $\begin{array}{c}\text { Provinsi } \\
\text { Sulawesi Selatan }\end{array}$ & $\begin{array}{c}\text { Provinsi } \\
\text { Sulawesi } \\
\text { Selatan }\end{array}$ \\
\cline { 1 - 3 } Kabupaten Kepulauan Selayar & 13,97 & 7,62 & & \\
Kabupaten Bantaeng & 15,02 & 7,59 & \multirow{2}{*}{21,04} & \multirow{2}{*}{7,31} \\
\cline { 1 - 3 } Kabupaten Takalar & 11,65 & 7,37 & \\
\hline Kabupaten Bone & 14,81 & 7,38 & & \\
\hline Kabupaten Luwu Utara & 14,07 & 7,62 & & \\
\hline
\end{tabular}

Sumber : Hasil Olah Data 2021

Seperti yang dilihat pada tabel di atas bahwa rata-rata PDRB Perkapita Kabupaten Kepulauan Selayar Bantaeng, Kabupaten Takalar, Kabupaten Bone, dan Kabupaten Luwu Utara masih sangat rendah dibandingkan dengan PDRB Perkapita Provinsi Sulawesi Selatan. Hal ini di sebabkan karena Kabupaten Kepulauan Selayar, Kabupaten Bantaeng, Kabupaten Takalar, Kabupaten Bone, dan Kabupaten Luwu Utara masih di dominasi oleh sektor pertanian sebagai struktur ekonomi, sebagai 
berikut: Kabupaten Kepulauan Selayar memiliki keunggulun kompetitif dan nilai kontribusi yang besar dalam perekonomian Kabupaten Kepulauan Selayar dalam hal ini yaitu sektor pertanian pada komoditas tanaman pangan, komoditas yang paling unggul untuk dijadikan basis sektor tanaman pangan di Kabupaten Kepulauan Selayar adalah jagung, kacang tanah, ubi kayu dan ubi jalar. Selain itu Kabupaten Kepulauan Selayar merupakan penghasil kopra terbesar di Sulawesi Selatan. Seiring dengan anjoknya harga kopra nasional berdampak pada petani kelapa/kopra pada semua wilayah yang ada di Indonesia, dampaknya juga berimbas ke petani kopra di Kabupaten Kepulauan Selayar. Sehingga pendapatan daerah mengalami kendala yang bisa mengakibatkan menurunnya PDRB Kabupaten Kepulauan Selayar. Sektor pertanian adalah sektor yang sangat di andalkan Kabupaten Bantaeng karena sebagian besar penduduknya berprofesi sebagai petani. Kentang adalah salah satu tanaman holtikultura yang paling menonjol. Selain kentang, holtikultura lainnya adalah kol, wortel, dan buah-buahan seperti pisang dan manga.

Kabupaten Takalar memiliki potensi sumber daya alam yang sangat melimpah, diantaranya yaitu tambak seluas 500 hektar dengan sekali panen bisa menghasilkan 40 sampai 50 ton udang, rumput laut yang menjadi potensi di Kabupaten Takalar karena mempunyai lawi-lawi yang jauh lebih baik dari daerah lain, serta memiliki objek wisata yang banyak diminati bagi parawisatawan lokal diantaranya Pantai Topojawa, dan Galesong. Kabupaten Bone memiliki komoditi unggulan di sektor pertanian dan sektor industri pengolahan, seperti : industri pengolahan bahan pangan, industry kimia Agro Non Pangan dan hasil hutan, industri logam mesin dan elektronika, industri pengolahan hasil pertanian dan lain sebagainya. Kabupaten Luwu Utara memiliki potensi di sektor pertanian dan perkebunan. Untuk perkebunan, komoditas utama yang paling signifikan adalah kakao dan sawit. Kakao Kabupaten Luwu Utara menjadi salah satu penyumbang terbesar di Provinsi Sulawesi Selatan, selain itu ada juga potensi rempah, kopi, dan lain-lain. sedangkan dari sektor pertambangan yaitu emas dan rampi.

\section{d. Daerah relative tertinggal (Kuadran IV)}

Yang termasuk dalam kategori daerah relative tertinggal (Kuadran IV) yaitu ; Kabupaten Bulukumba, Kabupaten Jeneponto, Kabupaten Gowa, Kabupaten Sinjai, Kabupaten Maros, Kabupaten Barru, Kabupaten Soppeng, Kabupaten Wajo, Kabupaten Sidrap, Kabupaten Pinrang, Kabupaten Enrekang, Kabupaten Luwu, Kabupaten Tana Toraja, Kota Pare-pare, Kota Palopo, dengan rata-rata PDRB Perkapita dan rata-rata laju pertumbuhan ekonomi di bawah rata-rata PDRB Perkapita Provinsi Sulawesi Selatan, dapat lihat pada tabel berikut ini :

Tabel 14. Hasil Analisis Tipologi Klassen Tahun 2005-2019

\begin{tabular}{|c|c|c|c|c|}
\hline \multirow[t]{2}{*}{ Kabupaten/kota } & $\begin{array}{c}\text { Rata-rata PDRB } \\
\text { Perkapita }\end{array}$ & $\begin{array}{l}\text { Rata-rata laju } \\
\text { pertumbuhan } \\
\text { ekonomi }\end{array}$ & $\begin{array}{c}\text { Rata-rata PDRB } \\
\text { Perkapita }\end{array}$ & $\begin{array}{c}\text { Rata-rata laju } \\
\text { pertumbuhan } \\
\text { ekonomi }\end{array}$ \\
\hline & Kabupaten/kota & Kabupaten/kota & $\begin{array}{c}\text { Provinsi } \\
\text { Sulawesi Selatan }\end{array}$ & $\begin{array}{c}\text { Provinsi Sulawesi } \\
\text { Selatan }\end{array}$ \\
\hline Kabupaten Bulukumba & 11,46 & 6,52 & \multirow{11}{*}{21,04} & \multirow{11}{*}{7,31} \\
\hline Kabupaten Jeneponto & 9,68 & 6,16 & & \\
\hline Kabupaten Gowa & 9,78 & 7,22 & & \\
\hline Kabupaten Sinjai & 15,46 & 6,82 & & \\
\hline Kabupaten Maros & 20,89 & 6,80 & & \\
\hline Kabupaten Barru & 14,60 & 6,57 & & \\
\hline Kabupaten Soppeng & 15,94 & 6,75 & & \\
\hline Kabupaten Wajo & 18,68 & 6,09 & & \\
\hline Kabupaten Sidrap & 15,84 & 7,24 & & \\
\hline Kabupaten Pinrang & 18,49 & 6,93 & & \\
\hline Kabupaten Enrekang & 12,38 & 6,06 & & \\
\hline Kabupaten Luwu & 14,62 & 6,96 & \multirow{4}{*}{21,04} & \multirow{4}{*}{7,31} \\
\hline Kabupaten Tana Toraja & 9,89 & 6,82 & & \\
\hline Kota Pare-pare & 18,89 & 7,15 & & \\
\hline Kota Palopo & 17,16 & 7,16 & & \\
\hline
\end{tabular}

Sumber : Hasil Olah Data 2021

Hal ini dikarenakan kabupaten/kota yang ada di Sulawesi Selatan masih sangat mengandalkan sektor pertanian sebagai sektor unggulan tiap daerah, sehingga perputaran uang yang terjadi pada 
masyarakat dengan pekerjaan pokok pertanian dan perkebunan masih sangat rendah. Hal ini disebabkan karena Kabupaten/kota pada umumnya mengunggulkan sektor pertanian sebagai sumber penghasilan, serta jumlah penduduk juga sangat mempengaruhi tingkat PDRB Perkapita kabupaten/kota di Provinsi Sulawesi Selatan, karena jika PDRB suatu daerah meningkat dengan laju pertumbuhan penduduk yang tinggi, maka PDRB Perkapitanya akan rendah seperti halnya di Kabupaten Gowa.

\section{Analisis Disparitas Pendapatan Antar Kabupaten/Kota Menggunkan Alat Analisis Indeks Williamson}

Perbedaan karakteristik wilayah berupa sumber daya alam merupakan salah satu faktor yang mendorong terjadinya ketimpangan pembangunan selain dari faktor lainnya seperti sumber daya manusia, sumber daya sosial, sumber daya buatan (ketersediaan sarana dan prasarana sosialekonomi), karakteristik ekonomi wilayah, dan kebijakan pemerintah daerah (Anwar, 2005). Seiring gencarnya pembangunan di suatu wilayah maka akan diikuti oleh ketimpangan pembangunan. Fenomena ini menunjukkan bahwa dalam proses pembangunan yang bersifat spasial masalah ketimpangan akan muncul. Kondisi ini menunjukkan terjadinya perbedaan tingkat pembangunan dan tingkat kesejahteraan pada suatu wilayah, beberapa wilayah mencapai pertumbuhan ekonomi yang cepat sementara dibeberapa wilayah lainnya mengalami pertumbuhan yang lambat. Hasil perhitungan menggunakan Indeks Williaamson menunjukkan terjadinya disparitas pendapatan antar Kabupaten/kota di Provinsi Sulawesi Selatan Tahun 2005-2019 yang ditunjukkan dengan nilai Indeks Williamson yang lebih besar dari 0 .

Kesenjangan yang paling rendah terdapat pada Kabupaten Wajo, Kota Pare-pare dan kota Palopo dengan rata-rata nilai Indeks Williamson tahun 2005-2019 sebesar 0,02. Diperkirakan penurunan disparitas pendapatan antar daerah ini salah satunya disebabkan oleh pelaksanaan otonomi daerah dan desentralisasi fiskal, otonomi daerah dan desentralisasi fiskal memberikan perubahan yang signifikan terhadap pemerataan dan kesejaterahan, karena kebijakan ditentukan sesuai dengan potensi setiap daerah dan lebih mampu memperhitungkan kondisi regional dalam penyediaan barang-barang, seperti infrastruktur, pendidikan, dan kesehatan (Thornton, 2006). Menurut Pose (2007) menyatakan bahwa desentralisasi fiskal memberikan perubahan yang signifikan terhadap pemerataan dan kesejahteraan. Hal ini dikarenakan pemerintah daerah (dengan asumsi lebih dekat dengan rakyat) lebih cakap dalam membuat kebijakan yang menentukan barang publik yang dibutuhkan di daerahnya. Dengan demikian pemerintah daerah menghasilkan fungsi alokasi yang lebih efisien.

Kesenjangan yang paling tinggi terdapat pada Kota Makassar dengan rata-rata nilai Indeks Williamson tahun 2005-2019 sebesar 0,40. Ketimpangan ini terjadi karena adanya konsentrasi kegiatan ekonomi sektor basis di daerah tertentu, sehingga yang menikmati hasilnya hanya sebagian, serta adanya perbedaan sumber daya alam yang di miliki antar Kabupaten/kota sehingga berpengaruh terhadap kondisi lingkungan dan infrastruktur antar daerah. Infrastruktur di bidang kesehatan dan pendidikan harus lebih di utamakan dan ditingkatkan oleh pemerintah Provinsi Sulawesi Selatan karena ini merupakan faktor yang sangat menunjang agar sumber daya manusia terus berkembang dan mampu mengelolah sumber daya alam dengan baik agar memiliki nilai tambah yang tinggit demi kemajuan daerah itu sendiri. Pembangunan infrastruktur ini harus merata di setiap daerah di Provinsi Sulawesi Selatan agar ketimpangan antar daerah berkurang atau tidak ada lagi.

\section{Hubungan Pertumbuhan Ekonomi dan Disparitas Pendapatan Terhadap Kesejahteraan Antar Daerah Kabupaten/kota di Provinsi Sulawesi Selatan. \\ a. Hubungan Pertumbuhan Ekonomi Terhadap Kesejahteraan Masyarakat}

Secara parsial variabel pertumbuhan ekonomi mempunyai hubungan signifikan terhadap kesejateraan masyarakat dengan nilai yang negatif, artinya variabel pertumbuhan ekonomi berpengaruh terhadap kesejahteraan masyarakat, dimana tanda negatif menunjukkan bahwa peningkatan pertumbuhan ekonomi akan menurunkan kesejahteraan masyarakat antar daerah Kabupaten/kota di Provinsi Sulawesi Selatan. Sejalan dengan teori pertumbuhan klasik dalam penelitian Siti Wasingah (2016), peningkatan jumlah penduduk akan menurunkan tingkat kegiatan ekonomi karena produktivitas setiap penduduk telah menjadi negatif, maka kemakmuran masyarakat menurun, ekonomi akan mencapai tingkat perkembangan yang sangat rendah pada keadaan ini 
pendapatan pekerja hanya mencapai tingkat cukup hidup (subsistence). Hasil penelitian ini tidak sejalan dengan landasan teori yang dikemukakan oleh Kuznet yang menyatakan bahwa salah satu karakteristik pertumbuhan ekonomi modern adalah tingginya pertumbuhan output perkapita (Todaro, 2006). Pertumbuhan output yang dimaksud adalah PDRB perkapita, tingginya pertumbuhan output menjadikan perubahan pola konsumsi dalam pemenuhan kebutuhan. Artinya semakin meningkatnya pertumbuhan ekonomi maka akan semakin tinggi pertumbuhan output perkapita dan merubah pola konsumsi dalam hal ini tingkat daya beli masyarakat akan semakin tinggi. Tingginya daya beli masyarakat akan meningkatkan Indeks Pembangunan Manusia karena daya beli masyarakat merupakan salah satu indikator komposit dalam IPM yang disebut indikator pendapatan.

Hasil penelitian ini sejalan dengan hasil penelitian yang dilakukan Ratu Eva Febriani dan Yusnida (2020) yang menyatakan bahwa pertumbuhan ekonomi berpengaruh secara signifikan dengan nilai yang negatif terhadap kesejahteraan masyarakat di Provinsi Bengkulu. Namun berbanding terbalik dengan hasil penelitian yang dilakukan oleh I Komang Oka Artana Yasa dan Sudarsana Arka (2015) yang menyatakan bahwa pertumbuhan ekonomi berpengaruh positif dan signifikan terhadap kesejahteraan masyarakat Provinsi Bali. Dari hasil regresi pada tabel 11 terlihat bahwa meningkatnya pertumbuhan ekonomi justru memberi dampak penurunan terhadap kesejahteraan masyarakat, begitu pula sebaliknya, jika pertumbuhan ekonomi mengalami perlambatan maka akan mendorong kenaikan pada kesejahteraan masyarakat antar daerah kabupaten/kota di Provinsi Sulawesi Selatan. Hal ini dikarenakan masih terpusatnya pengelolaan sumber-sumber pendapatan pada kelompok atau individu tertentu. Sumberdaya yang seharusnya dapat dinikmati oleh semua orang ternyata hanya dinikmati oleh segelintir saja. Investasi yang masuk di kabupaten/kota Provinsi Sulawesi Selatan belum mampu dinikmati oleh masyarakat secara menyeluruh. Ada beberapa daerah di Provinsi Sulawesi Selatan yang masih tertinggal pembangunannya dibandingkan daerah lainnya terutama daerah yang jauh dari pusat pemerintahan.

Pada dasarnya hasil pembangunan ekonomi tidak hanya menunjukkan arah pada pencapaian angka pertumbuhan ekonomi tertentu. Badrudin (2011) menyatakan bahwa keberhasilan pembangunan ekonomi tidak hanya didasarkan pada kecepatan pertumbuhan ekonomi, tetapi lebih pada peningkatan kesejahteraan sosial. Itu sebabnya, pemerintah kabupaten/kota di Provinsi Sulawesi Selatan perlu membedakan makna antara pertumbuhan ekonomi dan pembangunan ekonomi. Kedua istilah ini memiliki makna dan definisi yang berbeda sehingga dampak yang diberikan terhadap perekonomian kabupaten/kota juga berbeda. Dengan demikian, pertumbuhan ekonomi yang terjadi di kabupaten/kota Provinsi Sulawesi Selatan tidak selalu menciptakan kekayaan bagi masyarakat.

\section{b. Hubungan Disparitas Pendapatan Terhadap Kesejahteraan Masyarakat}

Secara parsial variabel disparitas pendapatan berpengaruh signifikan terhadap kesejahteraan masyarakat dengan nilai yang negatif, yang artinya variabel disparitas pendapatan berpengaruh terhadap kesejahteraan masyarakat, dimana tanda negatif menunjukkan bahwa peningkatan disparitas pendapatan akan menurunkan kesejahteraan masyarakat antar daerah Kabupaten/kota di Provinsi Sulawesi Selatan. Menurut Patta (2012), ketidakmerataan distribusi pendapatan akan berdampak buruk terhadap pertumbuhan ekonomi dan kemudian akan berdampak buruk juga terhadap kesejahteraan masyarakat suatu wilayah. Tambunan (dalam Savitri, 2008) menyatakan disparitas distribusi investasi antar daerah dapat juga dianggap sebagai salah satu faktor utama yang menyebabkan terjadinya disparitas pendapatan antar daerah. Investor cenderung melakukan investasi pada daerah-daerah maju, karena memudahkan akses pada fasilitas-fasilitas tertentu. Berdasarkan atas permasalahan tersebut Kuznets (dalam Daryanto, 2012) mengatakan bahwa dalam jangka pendek pertumbuhan pendapatan perkapita dan ketimpangan mempunyai korelasi positif, namun korelasi tersebut menjadi negatif dalam jangka panjang.

Hasil penelitian ini sejalan dengan penelitian I Komang Oka Artana Yasa dan Sudarsana Arka (2015) yang menyatakan bahwa disparitas pendapatan antardaerah berpengaruh negatif dan signifikan terhadap kesejahteraan masyarakat, serta sejalan dengan penelitian Abdel-Rahman dan Ping Wang (1997), yang menunjukkan adanya hubungan negatif antara ketimpangan pendapatan antar daerah dengan kesejahteraan masyarakat, ketimpangan pendapatan antar daerah yang semakin melebar akan menurunkan tingkat kesejahteraan masyarakat. Adanya hubungan negatif antara nilai disparitas pendapatan dengan kesejahteraan masyarakat, memberi indikasi bahwa kesejahteraan masyarakat antar Kabupaten/kota di Provinsi Sulawesi Selatan ditentukan oleh menurunnya 
disparitas pendapatan. Semakin melebarnya ketimpangan antar Kabupaten/Kota akan menyebabkan menurunnya kesejahteraan masyarakt. Menurunnya angka disparitas pendapatan antar Kabupaten/Kota akan berdampak pada terciptanya pemerataan pembangunan pada setiap Kabupaten/Kota di Provinsi Sulawesi Selatan dan pada akhirnya kesejahteraan masyarakatpun akan meningkat. Berdasarkan hasil analisis yang telah diuraikan sebelumnya maka dapat ditarik kesimpulan bahwa:

1. Pertumbuhan ekonomi antar Kabupaten/Kota di Provinsi Sulawesi Selatan Tahun 2005-2019 mengalami fluktuasi.

2. Klasifikasi Tipologi Daerah Provinsi Sulawesi Selatan Tahun 2005-2019 Berdasarkan Tipologi Klassen, terdapat daerah yang dikategorikan sebagai daerah maju dan tumbuh cepat (Kuadran I), daerah maju tapi tertekan (Kuadran II), daerah berkembang cepat (Kuadran III) dan daerah relatif tertinggal (Kuadran IV)

3. Indeks Williamson menunjukkan terjadinya kesenjangan antar kabupaten/kota di Provinsi Sulawesi Selatan selama tahun 2005-2019.

4. Secara parsial Pertumbuhan ekonomi dan disparitas pendapatan berpengaruh signifikan terhadap kesejahteraan masyarakat antar daerah kabupaten/kota di Provinsi Sulawesi Selatan.

5.

\section{Saran} berikut:

Berdasarkan hasil analisis yang telah diuraikan sebelumnya maka dapat ajukan saran sebagai

1. Pemerintah daerah dalam programnya disamping mengejar laju pertumbuhan ekonomi yang tinggi, diharapkan pula mampu lebih intensif melaksanakan upaya pemerataan distribusi pendapatan serta pembangunan manusia yang tentunya berdampak pada kesejahteraan masyarakat anatar Kabupaten/Kota Provinsi Sulawesi Selatan dan Pemerintah daerah dalam kebijakan pembangunan jangka menengah ataupun jangka panjang agar memprioritaskan pembangunan yang berdimensi spasial tidak hanya sektoral, namun juga memperhatikan di mana lokasi geografis aktivitas ekonomi dan menurunkan ketimpangan pendapatan antar Kabupaten/Kota Provinsi Sulawesi Selatan.

2. Diharapkan pemerintah daerah harus melakukan pengembangan teknologi dan menarik investor dari luar daerah untuk mengembangkan produk-produk unggulan dari tiap daerah guna untuk meningkatkan pendapatan daerah.Berdasarkan hasil penelitian dan kesimpulan yang telah dipaparkan maka selanjutnya dikemukakan beberapa saran sebagai berikut:

\section{DAFTAR PUSTAKA}

Adiat, Farris. dan Achmad Tjachja. Analisis Kesenjangan Wilayah dan Kesenjangan Pendapatan di Indonesia Tahun 2015-2018. Fakultas Sains dan Teknologi. Uin Syarif Hidayatullah. Jakarta.

Andiny, Puti. dan Pipit Mandasari. 2017. Analisis Pertumbuhan Ekonomi dan Kemiskinan Terhadap Ketimpangan di Provinsi Aceh. Jurnal Penelitian Ekonomi Akuntansi (Jensi), Vol. 1, No. 2, Desember 2017. Fakultas Ekonomi, Universitas Samudra. Langsa Aceh.

Arfah, A., Olilingo, F. Z., Syaifuddin, S., Dahliah, D., Nurmiati, N., \& Putra, A. H. P. K. (2020). Economics During Global Recession: Sharia-Economics as a Post COVID-19 Agenda. The Journal of Asian Finance, Economics, and Business, 7(11), 1077-1085.

Arifin, M. Y. R. (2019). Perekonomian Nasional Dalam Perspektif Undang-Undang Dasar 1945 Negara Republik Indonesia. Celebes Equilibrum Journal, 1(1), 26-31.

Arsyad, Lincolin. 2010. Ekonomi Pembangunan. Edisi Kelima. Unti Penerbit dan Percetakan STIM YKPN Yogyakarta.

Asj'ari, Fachrudy. 2015. Pengaruh Pertumbuhan Ekonomi Terhadap Kesejahteraan Keluarga Bukan Pegawai Negeri Sipil di Surabaya. Majalah Ekonomi ISSN 1411-9501: Vol XX No 1, Juli 2015. Dosen Prodi Manajemen Unipa Surabaya.

Badan Pusat Stastik. 2015. Pertumbuhan Ekonomi Sulawesi Selatan Tahun 2014. No. 5 Februari 2015. BPS, Provinsi Sulawesi Selatan.

Badan Pusat Statistik. 2010. Seri 2010 Produk Domestik Regional Bruto Per Kapita Atas Dasar Harga Konstan 2010 Menurut Provinsi, 2010-2018 (Ribu Rupiah). BPS. Indonesia.

Bank Indonesia. Laporan Perekonomian Provinsi Sulawesi Selatan Mei 2020 (terbit setiap triwulan). BI, Provinsi Sulawesi Selatan.

Bareksa 10 Juni 2016 Pertumbuhan Ekonomi Sulawesi Selatan Selalu di Atas Nasional, Apa Pemicunya? 
Febriani, Ratu Eva dan Yusnida. 2020. Kajian Kesejahteraan di Provinsi Bengkulu : Sebuah Temuan Dari Analisis Jalur. Vol. 2, No. 1, Hal. 16-35, Juli 2020.Jurusan Ekonomi Pembangunan. Fakultas Ekonomi dan Bisnis. Universitas Bengkulu, Indonesia.

Febrianto, Ramadhan. 2017. Analisis Pengaruh Pertumbuhan Ekonomi, Belanja Daerah, dan Ipm Terhadap Ketimpangan Pendapatan Antar Daerah Di Provinsi Jawa Timur 2011-2015. Fakultas Ekonomi dan Bisnis Universitas Brawijaya Malang

Dahliah, D., Kurniawan, A., \& Putra, A. H. P. K. (2020). Analysis and strategy of economic development policy for SMEs in Indonesia. The Journal of Asian Finance, Economics, and Business, 7(5), 103-110.

Destingsih, Rian. Dkk. 2019. Ketimpangan Wilayah di Daerah Istimewa Yogyakarta Tahun 2010-2018 Melalui Pendekatan Indeks Williamson. Prosiding Seminar Nasional dan Call For Papers. Fakultas Ekonomi. Universitas Tidar.

Hipziwaty, Baiq. Dkk. 2019. Pertumbuhan Ekonomi, Disparitas Pendapatan dan Kesejahteraan Kabupaten/Kota di Provinsi Nusa Tenggara Barat. Vol. 13, No. 1, Maret 2019. 59-70. Alumnus, Dosen Fakultas Ekonomi Universitas Negeri Mataram.

Iskandara, Azwar. dan Rahmaluddin Saragih. 2018. Analisis Kondisi Kesenjangan Ekonomi Daerah : Studi Kasus Kabupaten/Kota di Sulawesi Selatan. Jurnal Info Artha Vol.2, No.1, (2018), Hal.37-52. Balai Diklat Keuangan Makassar.

Machmud, Amir. 2016. Perekonomian Indonesia Pasca Reformasi. Cetakan Kesatu. Penerbit Erlangga. Jakarta.

Mulyadi, Muhammad. 2018. Pengaruh Pertumbuhan Ekonomi dan Pendapatan Daerah Terhadap Disparitas Pendapatan Di Tinjau Dari Perspektif Ekonomi Islam (Studi Komparasi Pada Kota Metro dan Kota Bandar Lampung ). Fakultas Ekonomi dan Bisnis Islam. Universitas Islam Negeri Raden Intan. Lampung.

Nababan, Riris Lastri. dan Banatul Hayati. 2019. Analisis Disparitas Pendapatan dan Faktor Penentu Pertumbuhan Ekonomi Provinsi-Provinsi di Pulau Jawa Tahun 2011-2016. Diponegoro Journal Of Economic Development Volume 5, Nomor 3, Tahun 2019, Halaman 1-15. Fakultas Ekonomika dan Bisnis. Universitas Diponegoro. Semarang.

Nazir, M., Murdifin, I., Putra, A. H. P. K., Hamzah, N., \& Murfat, M. Z. (2020). Analysis of Economic Development Based on Environment Resources in the Mining Sector. The Journal of Asian Finance, Economics, and Business, 7(6), 133-143.

Ningsih, Endang Kusdiah. Dkk. 2019. Pengaruh Pertumbuhan Ekonomi Terhadap Disparitas Pembangunan Di Propinsi Sumatera Selatan. Jurnal Ekonomi Manajemen dan Akuntansi Vol. 15, No. 1, Juli 2019. Universitas IBA Palembang. Indonesia.

Olilingo, F. Z., \& Putra, A. H. P. K. (2020). How Indonesia Economics Works: Correlation Analysis of Macroeconomics in 2010-2019. The Journal of Asian Finance, Economics and Business (JAFEB), 7(8), 117130 .

Putra, A. H., Aswari, A., Arifin, M. Y. R., \& Rina, R. (2018). Quantitative series: Factors analysis effects of government regulation number 46 the year 2013 for SME's by justice, convenience, and simplicity of tax aspects. Substantive Justice International Journal of Law, 1(2), 65-81.

Prawoto, Nano. 2019. Pengantar Ekonomi Makro. Edisi Kesatu. PT RajaGrafindo Persada, Depok.

Rahmat, Basuki. 2013. Analisis Ketimpangan Wilayah Di Provinsi Sulawesi Selatan Sebelum Dan Setelah Desentralisasi Fiskal 1990-2011. Fakultas Ekonomi Dan Bisnis Universitas Hasanuddin, Makassar.

Ratriadi, Benni. 2009. Analisis Disparitas Pendapatan dan Pertumbuhan Ekonomi Kabupaten/Kota di Daerah Istimewa Yogyakarta Tahun 2003-2007. Fakultas Ekonomi. Universitas Negeri Semarang.

Sari, Norma Rita. 2013. Analisis Pertumbuhan Ekonomi dan Ketimpangan Pendapatan Antar Provinsi di Indonesia Tahun 2004-2010. Fakultas Ekonomi Universitas Diponegoro. Semarang.

Semailla, Baharuddin. Dan Ahri, Aril Reza. 2017. Metodologi Penelitian Kuantitatif. Cetakan Satu. Arus Timur, Makassar.

Sitorus, Devi Yanti Rahayu. 2012. Analisis Pertumbuhan dan Ketimpangan Antar Kabupaten/Kota di Provinsi Kalimantan Timur Tahun 2001-2009. Fakultas Ekonomi Universitas Diponegoro. Semarang.

S, Dyah Hapsari Amalina. Dkk. 2013. Pertumbuhan Inklusif : Fenomena Pertumbuhan Inklusif Di Kawasan Indonesia Bagian Barat Dan Indonesia Bagian Timur. Jurnal Ekonomi dan Kebijakan Pembanguan, hlm. 85-112 Vol 2 No 2. Staf Kementerian Perdagangan dan Mahasiswa Magister Program Studi Ilmu Ekonomi, FEM IPB dan Staf Pengajar FEM IPB.

Sukirno, Sadono. 2015. Ekonomi Pembangunan: Proses, Masalah, dan Sasaran Kebijakan. Edisi Kedua. Prenamedia Group. Jakarta.

Supriyanto. 2020. Analisis Pertumbuhan Ekonomi dan Penetapan Sektor Unggulan di Provinsi Sulawesi Selatan. Program Pascasarjana, Universitas Muslim Indonesia.

Suzana, Benu Olfie L. dan Gene H. M. Kapantow. Faktor-Faktor Yang Mempengaruhi Ketimpangan Distribusi Pendapatan di Sulawesi Utara.

Tapparan, S. R. (2020). Analisis Korelasi Infrastruktur Jalan Terhadap Pertumbuhan Ekonomi Kabupaten Tana Toraja. Jurnal Ekonomika, 4(1), 68-72.

Todaro, Michael P. dan Stephen C. Smith. 2003. Pembangunan Ekonomi. Edisi Kesebelas. Penerbit Erlangga. Jakarta. 
Tussa'diah, Halima. 2019. Pengaruh Infrastruktur, Investasi, dan Pertumbuhan Ekonomi Terhadap Kesejahteraan Masyarakat Melalui Kesempatan Kerja di Kota Makassar. Fakultas Ekonomi dan Bisnis Islam. Universitas Islam Negeri Makassar.

Wicaksono, Cholif Prasetio. 2010. Analisis Disparitas Pendapatan Antar Kabupaten/Kota dan Pertumbuhan Ekonomi di Propinsi Jawa Tengah Tahun 2003-2007. Fakultas Ekonomi, Universitas Diponegoro. Semarang.

Widyastuti, Astriana. 2012. Analisis Hubungan Antara Produktivitas Pekerja dan Tingkat Pendidikan Pekerja Terhadap Kesejahteraan Keluarga di Jawa Tengah Tahun 2009. Economics Development Analysis Journal 1 (2) (2012). Fakultas Ekonomi. Universitas Negeri Semarang,. Indonesia.

Yasa, I Komang Oka Artana. dan Sudarsana Arka. 2015. Pengaruh Pertumbuhan Ekonomi dan Disparitas Pendapatan Antardaerah Terhadap Kesejahteraan Masyarakat Provinsi Bali. Jurnal Ekonomi Kuantitatif Terapan Vol. 8, No. 1 Februari 2015. Fakultas Ekonomi Dan Bisnis. Universitas Udayana.

Yuniarsih, Eka Triana dan Sandi Nugroho. 2016. Potensi Wilayah Berdasarkan Basis Sektor Tanaman pangan di Kepulauan Selayar Provinsi Sulawesi Selatan. Balai Pengkajian Teknologi Pertanian Sulawesi Selatan 